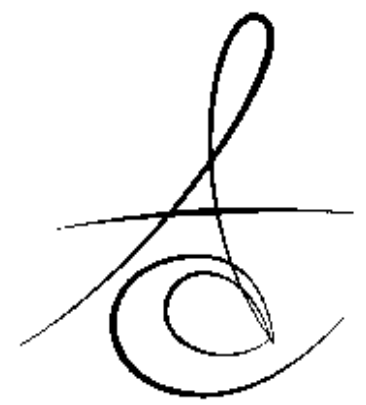

\title{
MİKROGERİLİM BAĞLANMA DAYANIM TESTİ VE SONUÇLARINI ETKİLEYEN ETKENLER
}

\section{MICROTENSILE BOND STRENGTH TEST AND EFFECTING FACTORS OF THE TEST RESULTS}

\author{
Dr. Neslihan TEKÇE*
}

\author{
Prof.Dr.Mustafa DEMİRCí ${ }^{* *}$
}

\author{
Makale Kodu/Article code: 1072 \\ Makale Gönderilme tarihi: 01.02 .2013 \\ Kabul Tarihi; 15.05 .2013
}

\section{ÖZET}

Kompozit restorasyonların klinik başarısını etkileyen en önemli faktör, bağlayıcı ara yüzeyin sağlamlığı ve sürekliliğidir. Adeziv diş hekimliğindeki gelişmeler ile birlikte, diş dokularına etkin bağlanma sağlanmış ve bunun sonucunda restoratif tedavinin başarısı elde edilmiştir. Günümüz adeziv sisteleri ile yaşanan esas zorluk, mine ve dentin gibi iki farklı dokuya bağlanmanın tam olarak sağlanabilmesidir. Dentin dokusuna bağlanma, mineye kıyasla daha karmaşıktır ve birçok faktörden etkilenir. Mikrogerilim bağlanma testlerinin avantajı ise bu farklııkların tek bir diş ile ölçülebilmesidir. Buna ilaveten mikrogerilim bağlanma testi birçok avantaja sahiptir. Tek bir diş ile verimli bir çalışma yapılabilmesi, dişlerin bölgesel farklılıklarının bağlanma dayanım değerleri üzerindeki etkisinin incelenebilmesi, çekme testi esnasında eşit kuvvet dağılımının daha fazla sağlanması ve tek bir örnek ile araştırmacılara kapsamlı bir çalışma imkânı sunması bunlardan bazılarıdır. Bununla birlikte bağlanma dayanım sonuçları birçok faktörden etkilenir. Hazırlanan örneklerin mikrogerilim test aparatına yerleştirilmesi, bağlayıcı ve dişin mekanik özellikleri, hazırlanan örneklerin şekli gibi birçok etken bağlanma dayanım değerleri üzerinde etkilidir. Bu makalede mikrogerilim bağlanma test metodu, farklı örnek hazırlama metotları, test sonuçlarını etkileyen faktörler ve bu test metodu kullanılarak bağlayıc sistemlerin bağlanma direncini inceleyen güncel çalışmalar derlenmiştir.

Anahtar Kelimeler: Mikrogerilim bağlanma testi, dentin bonding ajan, adezyon

\section{ABSTRACT}

One of the most important criteria for clinical success with composite restorative materials is the effectiveness and durability of the bonded interface. Development adhesive restorative materials provide an effective bond to dental tissue and, consequently, offering successful restorative treatment. The main challenge for dental adhesives is to provide an equally effective bond to two hard tissues of different nature. Bonding to enamel is now considered a durable, while bonding to dentin has been inconsistent. Originally, one of the key advantages of the microtensile bond strength test is the possibility to test different types of tooth tissue. Additionally, there are a lot of advantages of microtensile bond testing including, conservation of teeth, evaluation of regional bond strengths possible, more uniform loading, conductive to comprehensive examination of research question on same sample. However several factor effect of the finding of microtensile bond strength test like specimen fixation method to gripping device, mechanical properties of the adhesive and the adherents tested, or specimen shape. Different results could be obtained with any change in these testing variables. The aim of this rewiev was to evaluate the microtensile bond strength test method, different specimen geometries and the current studies that evaluate of the bond strength of dentin bonding agents using this method.

Keywords: Microtensile bond strength test, dentin bonding agent, adhesion.

\footnotetext{
* Ataşehir Ağız ve Diş Sağlığı Merkezi, İstanbul

** İstanbul Üniversitesi Diş Hekimliği Fakültesi Diş Hastalıkları ve Tedavisi Ana Bilim Dalı, İstanbul
} 


\section{GİRİş}

Adeziv restorasyonlar, operatif ve restoratif tedavi çalışmalarında yaygın bir kullanım alanı bulmaktadır. Adeziv materyallerin bağlanma performansını değerlendirmek için genellikle çekme (tensile) ve makaslama (shear) testleri yapılır. Günümüzde materyallerin bağlanma performansının geliştirilmesinde mikrogerilim ve mikroshear bağlanma dayanım testleri yaygın olarak kullanılmaktadır. Bağlanma testlerinin asıl amacı, materyallerin bağlanma dayanımlarının karşılaştırmalı olarak incelenebilmesidir. Laboratuar çalışmalarında, mikrosızıntı testleri de yaygın olarak kullanılmaktadır. Mikrosızıntı testlerinde çeşitli kavite tasarımları ve yerleştirme teknikleri değerlendirilebilmektedir. ${ }^{1}$

Adeziv materyallerin bağlanma dayanım testlerinde; ağız ortamını taklit eden in vitro şartların tam olarak oluşturulmasında; dentin yüzeyinin ıslaklığı, pulpal basınç ve dentin tabakasının kalınlığı oldukça önemlidir. Bağlayıcının amacı, restoratif materyalle diş dokuları arasında sıkı adaptasyonu sağlamaktır. Mine ve dentin yapısında ki farklılıklardan dolayı bunu başarmak zordur. Mine de mineral yapısı baskınken; dentinde su ve organik materyal mineye oranla fazladır. Dentinin nemli ve organik yapısı bağlanmayı karmaşıklaştırır. Çürükten etkilenmiş dentindeki kanallarda mineral birikmesi sonucu da bağlanma zorlaşır. Çürüksüz servikal bölgeler hipermineralize dentin ve denatüre kollajen içerdiği için yine ideal bağlanma değerleri elde edilemez. Dentinin derin tabakalarında kanalcık sayısı ve geniş̧liği arttığı için burada ıslaklık artar. Bu nedenle derin dentinden elde edilen bağlanma dayanım değerleri yüzeyel dentinden elde edilen değerlere göre daha düşüktür. Ayrıca asit uygulaması da kanalcıklar içindeki sıvının pulpadan yüzeye doğru hareketini sağlayarak bağlanmayı olumsuz etkiler. ${ }^{2}$

Adezivin, mine ve dentine bağlanma etkinliğinin ölçülmesi için farklı metodlar kullanılabilir. Bağlanma dayanımı, makro ya da mikro test yöntemleri ile ölçülebilir. Yöntem belirlenmesi bağlanma bölgesinin çapına bağlıdır. Makro bağlanma dayanımı, $3 \mathrm{~mm}^{2}$ den büyük bağlanma yüzeyleri için kullanılan yöntemdir, shear, tensile ya da push-out protokolü ile uygulanabilir. ${ }^{3,4}$

Günümüzde mikrogerilim bağlanma dayanım ( $\mu \mathrm{GBD})$ testleri en sık kullanılan laboratuar testleridir. Tek başına bağlanma dayanım değerlerinin materyalin özelliklerini tam olarak yansıtmadığı unutulmamalıdır. Elde edilen veriler deneysel etkenlere bağıdır. Kompozitin tipi, uygulanan kuvvet oranı, örnek büyüklüğü ve geometrisi, test metodu elde edilen verileri etkileyebilir. ${ }^{5}$ Bu nedenle deneylerin sonuçları karşılaştırıırken, sonuçların bu parametrelerden etkilenebileceği unutulmamalıdır. Bağlanma dayanımı testlerinden önemli klinik verilerde elde edilir. ${ }^{6,7}$

İdeal bağlanma dayanım testi; düşük teknik hassasiyette kullanım özelliğine sahip, kolay ve nispeten hızlı uygulanabilir olmalıdır. Genel olarak laboratuar testlerinin avantajları;

1- Spesifik parametre ve özelliklerle ilgili veri elde etmek hızlıdır,

2- Test metadolojisi nispeten kolaydır,

3- Belirli bir parametrenin ölçülebilmesine olanak sağlar,

4-Yeni ve/veya deneysel materyal/tekniğin, güncel altın standart performansı ile karşılaştırılabilmesine olanak sağlar,

5- Çok sayıda deneysel grup, tek bir çalışmada test edilebilir,

6- Nispeten basit ve pahalı olmayan protokol ve aletlerle çalışılabilmeyi sağlar. ${ }^{6}$

\section{Mikrogerilim Bağlanma Dayanım Testi}

$\mu$ GBD test yöntemini ilk olarak Sano ve arkadaşları 1994 yılında diş hekimliğinde kullanmıştır. Sano, mineralize ve demineralize dentinin elastik modülüsünü ve bağlanma dayanımını ölçmüştür. ${ }^{8}$ Mikrogerilim test yöntemi, bağlanmayı değerlendirirken çok yönlü incelemeye olanak sağlamıştır. ${ }^{9}$ Bu çok yönlülüğü, geleneksel shear ve tensile metodlarında elde edemeyiz. Diş hekimliği için çığır açan bu yöntem normal dentin, çürük dentin, sklerotik servikal dentin, MOD preparasyonları ve mine dokusuna, yüzlerce çeşit diş hekimliği materyalinin bağlanma dayanımlarının incelenmesi için kullanılmıştır. Mikro gerilme bağlanma dayanım ( $\mu \mathrm{GBD}$ ) testi, makro testlerin sağlayamadığı avantajları sağlar. Labaratuvarda örneklerin küçük çaplarda hazırlanarak, bağlanma dayanımlarının bu küçük parçalara göre değerlendirilmesi, dişten kaynaklanan yapısal farklılıkların incelenmesine de olanak sağlar. ${ }^{10-12}$

$\mu$ GBD testi, düz okluzal yüzeylerde hazırlanan kompozit bloklara uygulanır. Örneklerin çaplarına bağlı olarak her dişten farklı sayıda numune elde edilebilir. 13 Bağlanma yüzeyi, makro testlere göre çok küçük 
yüzeylerde değerlendirilir. Aynı dişten çok sayıda örnek elde edilerek ölçüm yapılabilir. Çekilmiş dişin farklı dentin yüzeylerinde bölgesel farkllıklar araştırılabilir. Geleneksel shear ve tensile testlerinde yüksek bağlanma dayanım değerleri elde edilebilirken, $\mu \mathrm{GBD}$ testlerinde küçük yüzeylere daha düzgün stres dağılımı ${ }^{14,15}$ sağlanarak, makro testlerde elde edilen değerlerden daha düşük bağlanma dayanım değerleri elde edilir. Ayrıca, $\mu \mathrm{GBD}$ çalışmaları restoratif materyalin adezyonu ve reçine bağlayıcıların uzun dönem durabiliteleri ile ilgili çok yönlü bilgi sağlar. ${ }^{16}$

Gerilme testlerinde örneklere uygulanan bağlayıcı ajanın bağlandığı alanın çapı (örneklerin çapı), 0,25 ile $12 \mathrm{~mm}^{2}$ arasında değişebilir. Ancak, $\mu$ GBD testinde bu alan ortalama $1 \mathrm{~mm}^{2}$ dir. ${ }^{13}$ Mikrogerilim testinde, çubuk şeklinde ki örnekler İsomet cihazında, elmas disklerle, yüksek hızda ve su soğutması altında hazırlanır. Hazırlanan örneklerin uzunluğu ortalama 10-24 mm arasında olmalıdır. Bu uzunluğun yarısı diş yapısı, diğer yarısı restoratif materyaldir. Uzunluğu $4 \mathrm{~mm}$ den küçük olan örnekler çekme testinde kullanılamaz. ${ }^{17}$

$\mu \mathrm{GBD}$ test yönteminde, örnekler bağlayıcı ara yüzü aşındırılarak (kum saati ya da dumbıl şeklinde) ya da aşındırımadan (düz dentin çubuğu şeklinde) farkı geometrilerde hazırlanabilir. ${ }^{17,18} \mathrm{Her}$ iki yöntemin avantaj ve dezavantajları vardır. Aşındırılmış mikro örnekler, kum saati şeklinde (hour-glass shaped) ya da halter sporunda kullanılan dumbıl şeklinde (Dumpleshaped) hazırlanabilir. Örneklerin kum saati şeklinde hazırlanması, ara yüzeyde daha iyi stres dağılımı sağlar. Aşındırma işlemi sırasında, bağlanma değerleri uygulayııının becerisinden etkilenir. Kum saati şeklinde hazırlanan mikro örneklerin aşındırma işlemi, yarı otomatik bir cihazla yapilır. Bu cihaza MicroSpecimen Former (University of lowa, lowa City, IA, Amerika) adı verilir. ${ }^{19} \mathrm{Bu}$ cihaz örneklerin kontrollü ve standart bir şekilde oluşturulabilmesini sağlar. $3,16,20,21$

Çubuk şeklinde ve dumbıl şeklinde aşındırılarak hazırlanan örneklerin stres dağılımı ve konsantrasyonu birbirine çok benzerdir. Ancak kum saati şeklinde hazırlanan örneklerin stres konsantrasyonu ve dağılım modeli dumbıl ve çubuk şekillerinden çok farklıdır. Kum saati şeklinde hazırlanan örneklerde, çekme testi sırasında diğer iki örneğe göre daha düşük kuvvetlerde kopmalar meydana gelir. Bunun nedeni, kum saati şeklinde hazırlanan örneklerde adeziv alana gelen streslerin daha geniş yüzeylere dağılmasıdır. ${ }^{18}$ Ayrıca kum saati şeklindeki örneklerin hazırlanışı sırasında, ara yüzde mikro çatlaklar oluşması da, daha düşük bağlanma dayanım değerleri elde edilmesine neden olur. ${ }^{17,18,20}$ Diğer iki yöntemle karşılaştıııldığında, örneklerin kum saati şeklinde hazırlanışı zordur ve hata yapma olasılığı yüksektir. Adeziv tabakanın kalınlığı ve bu alanda ki mevcut adezivin dağııımı, stres konsantrasyonunu ve bağlanma dayanım değerlerini etkiler.

$\mu G B D$ testi yapilırken ortaya çıkan önemli bir sorun, bir dişten kaç örnek elde edilebildiğidir. İkinci bir sorun ise test öncesi oluşan kopmalardır (pretesting failures). ${ }^{17}$ Meerbeek ve arkadaşları yaptıkları derleme çalışmasında, test esnasında ya da öncesinde (Pretest) kopan örneklerin, istatistik aşamasında genellikle üç şekilde değerlendirildiğini bildirmişlerdir: ${ }^{3}$

a-Test öncesi oluşan bütün kopmalar istatistiksel analizden çıkartılmışır. Bu durumda bağlayıcıların dentine bağlanma değerleri olduğundan yüksek görünür,

b-Bütün pre-test kopmaların değeri $0 \mathrm{MPa}$ olarak kabul edilmiş ve istatistiksel analize bu şekilde katımıştır. Bu durumda ise bağlanma dayanım değerleri olduğundan çok fazla düşme göstermiştir,

c-Önceki iki yaklaşıma bir modifikasyon getirilmiş ve 0 bağlayıcı gruba ait en düşük $\mu \mathrm{GBD}$ değeri, test öncesi kopan örneklerin değeri olarak kabul edilmiş ve bu şekilde istatiksel analize dahil edilmiştir. 3,22,23

Bilimsel açıdan kanıtlanamasa da bir bağlayıcı ajanın bağlanma dayanımının niteliksel olarak iyi ya da kötü oluğunu, $\mu \mathrm{GBD}$ testi ile ayırt etmek, geleneksel shear testlerine göre daha olasıdır. Bu nedenle günümüz bağlanma dayanımı ile ilgili yapılan çalışmalarının \%60'ı $\mu \mathrm{GBD}$ çalışmasıdır.,24 Diğer bağlanma dayanım testleri ile karşılaşıtııılığında $\mu \mathrm{GBD}$ testleri birçok avantaja sahiptir. ${ }^{24}$

$\mu G B D$ testinin yukarda detaylı olarak bahsetmiş bulunduğumuz avantaj ve dezavantajlarını şu şekilde özetleyecek olursak; ${ }^{17}$

Avantajlarl;

1- Bir dişten çok sayıda küçük örnek elde edilerek dişlerin verimli kullanılması , 10,25

2- Ara yüzeyde daha iyi stres dağıımı sağlanması,, 324

3- Hazırlanan örneklerde daha çok adeziv, daha az oranda koheziv kopma olması,

4- Yüksek bağlanma dayanım değerlerinin ölçülebilmesi,

5- Bölgesel bağlanma dayanım farklılıklarının 
değerlendirilebilmesi,

6- Tek bir dişte ki değişkenlerin hesaplanabilmesi,

7- Çürükden etkilenmiş dentin gibi çok küçük alanlarda test yapma olanağı sağlaması,

8- Kalan dentin kalınlığının bağlanmaya etkisinin değerlendirilebilmesi,

9- Diş kaynaklı değişkenliklerinin incelenebilmesi, ${ }^{26,27}$

10-Restorasyonların kavite duvarlarındaki bağlanma dayanımlarının incelenebilmesi, ${ }^{10}$

11-Kök dentinde bağlanma dayanımının değerlendirilebilmesi, ${ }^{10}$

12-Reçine esaslı kompozitin (RBC) bağlanmaya etkisinin incelenebilmes, ${ }^{28}$

13-Geleneksel çekme testine göre daha uniform kuvvet uygulaması, ${ }^{10}$

14-Ara yüzde ya da substratta, kayma ve geleneksel çekme testlerine göre daha az defekt oluştuğundan dolayı bağlanma dayanım değerlerinin daha yüksek değerlerde ölçülebilmesi, ${ }^{10}$

15-Farklı kavite tipleri ve yaşlandırma teknikleri gibi ilave araştırma yöntemlerinin incelenebilmesine olanak sağlaması, ${ }^{29}$

16-Örneklerin kısa difuzyon mesafeleri nedeniyle, yeterli suda ya da herhengi bir sıvıda bekletme ile oluşturulan hızlandırımış yaşlandırmaya elverişli olması, ${ }^{30}$

17-Makaslama etkisini en aza indirmesi, ${ }^{31,32}$

18-SEM ile kopma şeklinin kolayca belirlenebilmesi, ${ }^{33}$

19-Araştırmacıya aynı örnekte kapsamlı mekanik, morfolojik, kimyasal inceleme olanağı sağlanması, ${ }^{34,35}$

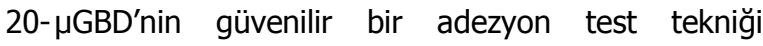
olması, ${ }^{36}$

21- GBDD test yönteminin yapay yaşlandırma yöntemleri için diğer yöntemlerden daha elverişli olması, ${ }^{6}$

22-Adeziv sistemler arasında ki farklılıkların makro shear yöntemlerine göre daha iyi belirlenebilmesi, ${ }^{37}$

Dezavantajlar;113,38

1- Yoğun labaratuar çalışması gerektirir,

2- $5 \mathrm{MPa}$ 'dan küçük olan, çok düşük bağlama dirençlerini ölçmede zorluk gösterir,

3- Örnekler kolaylıkla su kaybeder, dehydrate olabilir,

4- Örnekler kolaylıkla zarar görebilir,

5- Kopmadan sonra örnekler kaybolabilir ya da zarar görebilir,

6- Örneklerin uygun geometride hazırlanması özel ekipman gerektirir,

7- $\mu \mathrm{GBD}$ test örneklerinin hazırlanması esnasında dişte içsel defektler oluşabilir

8- Bağlayıcı ara yüzeyinde, hatalı uygulama prosedürlerinden kaynaklanan stresler ile bağlanma değerleri değişebilir. ${ }^{36}$

\section{faktörler:}

$\mu$ GBD test metodunda sonuçları etkileyen

Adeziv reçinenin bağlanma direnci birçok faktörden etkilenir. Ara yüzde mikro-mekanik ya da kimyasal bağlanma önemli bir faktördür. Bağlayıcının içeriğindeki herbir komponent bağlanma dayanımını direkt olarak etkiler. Adezivin kompozisyonu, solventi, asit içerip içermediği önemli faktörlerdendir. ${ }^{1}$ Pashley ve arkadaşları $^{38}$ etch and rinse sistemler için test sonuçlarını etkileyen değişkenleri Tablo 1'de özetlemişlerdir. Deneysel değişkenlerin sonuçları etkilemesini en aza indirmek için, istenmeyen etkileşimlerin oluşma şansının en aza indirilmesi gereklidir. ${ }^{17}$

\section{Mikrogerilim (Mikrotensile) Testi İle İlgili Yapılan Araştırmalarda En Fazla İrdelenen Değişkenler}

\section{Ortamın Isısı:}

Isı, polimerizasyon, buhar basıncı, akışkanlık, difüzyon gibi özellikleri etkiler. Adeziv ve kompozit uygulaması oda ISISI $40{ }^{\circ} \mathrm{C}$ yi aşmayan ortamlarda yapılmalıdır. Bunun sebebi ağız içi ısının $30^{\circ} \mathrm{C}$ 'nin üzerinde olmasıdır. In vitro ortamda buzdolabında saklanan dişler ya da materyaller $10^{\circ} \mathrm{C}$ ye kadar soğur. Araştırmacının uygun bağlanma dayanım değerleri elde edebilmesi için, substrat ve materyal ISısının ortalama $30^{\circ} \mathrm{C}$ olması gereklidir. ${ }^{17,18,39}$

\section{Biyolojik yapı:}

Çalışmalar gerilme (tensil) ve makaslama (shear) testleri için, sığır dişlerinin insan dişlerine iyi bir alternatif olabileceğini ileri sürmüştür. ${ }^{40,41}$ Reis ve arkadaşları, ${ }^{41}$ yeni çekilmiş 10 insan, 10 sığır, 10 domuz dişi kullanarak bu dokularda mine ve dentine olan bağlanma dayanım değerlerini incelemişlerdir. Araştırmacılar her üç gruptaki dişlerin $\mu G B D$ değerlerinin benzer çıktığını, ancak SEM incelemelerinde domuz dişlerinin mine yapısının, insan ve sığır dişlerinden çok farklı olduğunu bildirilmişlerdir. 
Tablo 1. Adeziv bağlanma dayanım ölçümlerinde test sonuçlarını etkileyen değişkenler ${ }^{38}$

\begin{tabular}{|c|c|}
\hline A.Substrat & B.Asit \\
\hline $\begin{array}{l}\text { 1.İnsan ya da sığır dişi. } \\
\text { 2.Yüzeyel, orta ya da derin } \\
\text { dentin. } \\
\text { 3.Okluzal, proksimal ya da } \\
\text { bukkal yüzey. } \\
\text { 4.Molar ya da keser diş. } \\
\text { 5.Yüzey muamelesi, zımpara } \\
\text { (Al } \mathrm{O}_{3} \text {, SIC, } 320,600,1000 \text { grit). } \\
\text { 6.Frez, elmas ya da karbit. } \\
\text { 7.Dişin çekimden sonra bekleme } \\
\text { süresi, ortamı ve dişin yaşı. }\end{array}$ & $\begin{array}{l}\text { 1.Asit uygulaması yapılarak ya da } \\
\text { yapılmadan. } \\
\text { 2.Uygulanan asitin tipi. } \\
\text { 3.Uygulanan asitin miktarı veya } \\
\text { tekrarı. } \\
\text { 4.Asitin uygulama süresi. } \\
\text { 5.Asitin pasif ya da aktif } \\
\text { uygulanışı. } \\
\text { 6. Yıkama süresi ve şekli. } \\
\text { 7.Kurutma süresi ve şekli. } \\
\text { 8.Tekrar yıkama işlemi } \\
\text { uygulanması. }\end{array}$ \\
\hline C. Primer & D. Bağlayıcı \\
\hline $\begin{array}{l}\text { 1.Primerin bütün yüzeyi örtmesi } \\
\text { ya da matriks ile uygulanması. } \\
\text { 2. Primerin miktarı. } \\
\text { 3.Uygulama ve yüzeyde } \\
\text { bekletme süresi. } \\
\text { 4.Yıkama ya da buharlaşma, } \\
\text { süresi. } \\
\text { 5.Işık uygulaması olması ya da } \\
\text { olmaması. } \\
\text { 6.Islak ya da kuru, ne kadar ıslak } \\
\text { ya da ne kadar kuru? }\end{array}$ & $\begin{array}{l}\text { 1.Uygulanan bondingin miktarı ve } \\
\text { bondingin uygulama süresi. } \\
\text { 2. Hava ile mi yayılıyor, ne oranda } \\
\text { ince ve ne oranda kuru? } \\
\text { 3. Bonding uygulanan alanın çapı. } \\
\text { 4. Basınçla mı uygulanıyor yoksa } \\
\text { basınç uygulamadan mı? } \\
5 \text {. Dentin kanalcıklarındaki dentin } \\
\text { sIVISı. } \\
\text { 6.Işıı uygulama süresi ve miktarı. }\end{array}$ \\
\hline E. Saklama Ortamı & F. Test Yöntemi \\
\hline $\begin{array}{l}\text { 1.Su, izotonik, tükürük. } \\
\text { 2.Oda ısısı. } \\
\text { 3.\% } 100 \mathrm{RH} \text { ya da su. } \\
\text { 4. Koruyucu içeriği? Sodyum azit, } \\
\text { timol, kloramin T. } \\
\text { 5.Pulpal basınç var ya da yok } \\
\text { varsa miktarı? } \\
\text { kompozisyonu. } \\
\text { 6.Saklama süresi? } 24 \text { saat, } 3 \text { ay, } \\
6 \text { ay, yll. } \\
\text { 7.Isısal stresler. Isı banyolarında } \\
\text { bekleme süresi. } \\
\text { 8.Mekanik yükleme uygulanıp } \\
\text { uygulanmaması. }\end{array}$ & $\begin{array}{l}\text { 1.Shear ya da } \mu \mathrm{GBD} \text {. } \\
\text { 2.Uygulanan stres oranı. } \\
\text { 3.Örneklerin hemen ya da } 24 \\
\text { saat sonra test edilmesi. } \\
\text { 4.Bağlanma yüzeyinin mine ya da } \\
\text { dentin olması. } \\
\text { 5.Mikrosızıntı ya da bağlanma } \\
\text { dayanımı. } \\
\text { 6.Bağlanma yüzeylerinin bölgesel } \\
\text { farkllıkları. } \\
\text { 7.Class } \vee \text { ya da Class I kavite. } \\
\text { 8.Konfügürasyon faktörü, düz } \\
\text { yüzeyi ya da kaviteye uygulanan } \\
\text { restorasyon. }\end{array}$ \\
\hline
\end{tabular}

\section{Sklerotik dentin:}

Aşınmış dişlerin bağlanma dayanım değerleri düşük çıkar, bu nedenle çalışmalarda sağlam dentine sahip olan dişler seçilmelidir. ${ }^{42}$ Karan ve arkadaşları, ${ }^{43}$ çürüksüz servikal lezyonlarda (sklerotik dentinde) mineral matriks oranının normal dentine kıyasla 2-3 kat fazla olduğunu bildirmişlerdir.

Tay ve arkadaşları, ${ }^{44}$ sklerotik dentinde bağlanma dayanım değerlerinin düşmesini 4 sebebe bağla mışlardır; (1) hibridize olmuş intermikrobiyel matriksin varlığı, (2) self-etch primerlerin hipermineralize yüzey tabakasını çözememesi, (3) hipermineralize yüzey tabakasında denature kollajenlerin varlığı, (4) aside dirençli sklerotik tıkaçların varlığı sonucu reçine uzantılarının oluşamaması.
Xie ve arkadaşları, ${ }^{45}$ tek ve iki aşamalı self etch sistemlerin sklerotik dentine bağlanma dayanımlarını incelemişler ve Clearfil SE Bond ve Clearfil S3 Bondun sklerotik dentine bağlanma dayanım değerlerinin normal dentinden anlamlı olarak düşük olduğunu bildirmişlerdir.

Tsai ve arkadaşları, ${ }^{46}$ tek aşamalı self etch adezivlerin asitleme kapasitesinin, çürüksüz servikal lezyonlardaki bağlanma değerleri üzerindeki etkisini incelemişlerdir. Araştırmacılar, Bond Force ( $\mathrm{pH}$ 2.3) ve $\mathrm{G}$ Bond Plus'ın ( $\mathrm{pH} 1.5$ ) sklerotik dentindeki bağlanma dayanım değerlerinin normal dentinden düşük olduğunu, pH'ları farklı olmasına rağmen iki bağlayıcının da sklerotik dentinde benzer bağlanma dayanım değerleri sergilediğini bildirmişlerdir. Araştırmacılar, daha güçlü asidik sistemlerin sklerotik dentinde bağlanmayı geliştirebileceğini ileri sürmüşlerdir.

Kwong ve arkadaşları, ${ }^{47}$ fosforik asit uygulaması yaparak ya da yapmadan self etch adeziv sistemin (Clearfil Liner Bond 2V) sklerotik dentine bağlanma dayanımını incelemişlerdir. Araştırmacılar, sklerotik dentine asit uygulaması yapılsa da yapılmasa da bağlanma dayanım değerlerinin, normal dentinden anlamlı olarak düşük olduğunu bildirmişlerdir. Araştırmacılar, sklerotik dentinde $\% 40^{\prime} \prime$ ık fosforik asit uygulamasının bağlanma dayanım değerlerini önemli ölçüde geliştirdiğini ileri sürmüşlerdir. Araştırmacılar, fraktografik analizde self etch primerin, sklerotik dentindeki hipermineralize alanı çözemediğini ve sklerotik dentindeki hipermineralize tabaka kalınlığının $0.5 \mu m^{\prime}$ den kalın olduğu durumlarda, hibrit tabakası oluşumunun gözlenmediğini bildirmişlerdir. Araştırmacılar, sklerotik dentinde güçlü asitlerin (\%35-40 fosforik asit) kullanılmasının sklerotik tıkaçları kısmen çözebileceğini, bununda dentin tübüllerine reçine infiltrasyonunu sağlayarak bağlanmayı geliştirebile- ceğini ileri sürmüşlerdir. ${ }^{47}$

\section{Çürükten etkilenmiş dentin:}

Yapılan çalışmalarda çürükten etkilenmiş dentinden elde edilen bağlanma dayanım değerlerinin normal dentine göre düşük olduğu ${ }^{25,48}$ bu nedenle yapılan çalışmaya göre çürüklü ya da çürüksüz dişlerin ayrılması gerektiği bildirilmiştir. ${ }^{49}$ Scholtanus ve arkadaşları, ${ }^{50}$ çeşitli adeziv sistemlerin çürük ve sağlam dentine bağlanma dayanım değerlerini incelemişlerdir. Araştırmacilar, SchotchBond XT1 ve Clearfil S3 Bond'un çürük dentine bağlanma dayanım değerlerinin sağlam dentine göre anlamlı olarak düşük olduğunu, 
Clearfil SE Bond'da ise anlamlılık olmadığını ifade etmişlerdir. Zanchi ve arkadaşları, ${ }^{51}$ Clearfil SE Bond ve Single Bondun çürük dentinde daha düşük bağlanma dayanım değerleri sergilediklerini bildirmişlerdir.

Yoshiyama ve arkadaşları ${ }^{52}$, Clearfil Liner Bond $2 V^{\prime}$ nin normal ve çürük dentine bağlanma dayanımlarını incelemişlerdir. Araştırmacılar, LinerBond 2V'nin normal dentinde bağlanma dayanım değerinin $45 \mathrm{MPa}$, çürükten etkilenmiş dentinde ise $30 \mathrm{MPa}$ olduğunu bildirmişlerdir. Araştırmacılar, TEM incelemelerinde normal dentinde hibrit tabaka kalınlığının 1 mikron, çürükten etkilenmiş dentinde ise 6-8 mikron olduğunu ileri sürmüşlerdir.

Yoshiyama ve arkadaşları, ${ }^{48}$ yaptıkları başka bir çürük çalışmasında self etch (ABF Bond) ve total etch (Single Bond) sistemlerin bağlanma dayanımlarını normal dentin, çürükten etkilenmiş dentin ve enfekte çürük dentinde incelemişlerdir. Araştırmacılar, ABF Bondun bağlanma değerlerinin normal dentinde 44.9MPa, çürükten etkilenmiş dentinde 25.3MPa, enfekte çürük dentinde ise 15.2MPa olarak, Single Bondun bağlanma değerlerini ise sırasıyla 50.9MPa, 28.8MPa ve 19.4MPa olarak tespit etmişlerdir.

Ceballos ve arkadaşları, ${ }^{25}$ dentin bağlayıcıların (Prime \& Bond NT, Scotchbond 1, Clearfil SE Bond or Prompt L-Pop) normal ve çürük dentine olan bağlanma dayanım değerlerini incelemişlerdir. Araştırmacılar, bütün bağlayıcıların normal dentinde çürük dentinden daha yüksek bağlanma dayanım değeri sergilediklerini ancak bu farklılığın sadece Prime \& Bond NT ve Clearfil SE Bond'da anlamlılık sergilediğini bildirmişlerdir. ${ }^{25}$

Ünlü ve arkadaşları, ${ }^{53}$ çürükten etkilenmiş dentine bağlanma etkinliğinin adeziv sistemlerin farklılı̆ından etkilendiğini bildirmişlerdir. Araştırmacılar, Clearfil SE Bond'un sağlam dentinde yüksek bağlanma dayanım değeri sergilerken, Optibond Solo Plus'ın çürükten etkilenmiş dentinde yüksek bağlanma dayanım değeri sergilediğini bildirmişlerdir. Araştırmacılar bu farklılıkta total etch sistemlerin self etch sistemlerden daha yüksek asit içerigi nedeniyle, hipermineralize olmus olan çürükten etkilenmis dentin kanallarını daha iyi açarak, reçinenin de dentin kanallarına daha iyi infiltre olmasını saglamasının etkisinin olabileceğini ileri sürmüşlerdir.

\section{Beyazlatma işlemi:}

Son yıllarda hidrojen peroksit ve karbamit peroksit (\%10-35) ile diş beyazlatma işlemi yaygın olarak kullanılmaktadır. Yapılan çalışmalarda, peroksit ile beyazlatma işleminin mine bağlanma dayanım direcine olumsuz etki yaptığı, hatta bu etkinin peroksit konsantrasyonu arttığında ve uzun beyazlatma işlemleri sonucunda daha da arttığı bildirilmektedir. ${ }^{\text {4-56 }}$ Bağlanma direncindeki bu azalmada peroksitin mine yüzey morfolojisinde meydana getirdiği yapısal değişikliklerin rolünün olabildiği gibi, asıl sebep peroksit tarafından salınan oksijenin polimerizasyon büzülmesine sebep olmasıdır. ${ }^{57}$

Leonetti ve arkadaşları, mineye 21 gün süreyle uygulanan \%16 karbamid peroksitin, Single Bond 2'nin dentine bağlanma dayanım değerlerini bir miktar düşürdüğünü ancak bunun anlamlılık sergilemediğini bildirmişlerdir. ${ }^{58}$

Cavalli ve arkadaşları, ${ }^{59}$ beyazlatma ajanlarının fluor içeren adezivlerin (Optibond FL, Optibond Solo Plus) mineye olan bağlanma dayanım değerleri üzerindeki etkisini incelemişlerdir. Araştırmacılar, \%10'luk karbamid peroksitin, her iki bağlayıcınında mineye olan bağlanma dayanım değerlerini anlamlı olarak düşürdüğünü ileri sürmüşlerdir.

Torres ve arkadaşları, ${ }^{60} \% 35^{\prime}$ lik hidrojen peroksit uygulamasının Single Bond 2'nin mineye olan bağlanma dayanım değerlerini anlamlı olarak düşürdüğünü bildirmişlerdir.

\section{Klorheksidin uygulaması:}

SEM incelemelerinde, klorheksidin uygulamasının dentin yüzeyindeki ve asit uygulanmış tübüllerdeki debrisleri ortamdan uzaklaştırdığı belirlenmiştir. ${ }^{61}$ Campos ve arkadaşları, ${ }^{62,63} \% 2^{\prime}$ lik klorheksidinin self etch (Clearfil S3 Bond) ya da total etch (Single Bond) sistemlerin dentine bağlanma dayanım değerlerinin süreye bağlı (6 ay) azalmalarını yavaşlattığını, daha düşük konsantrasyonlarda ki \%0.2'lik klorheksidinin ise Clearfil S3 Bondun bağlanma dayanım değerlerinin düşmesini engelleyemediğini ileri sürmüşlerdir. ${ }^{62}$ Campos ve arkadaşları, yaptıkları başka bir çalışmada $\% 0.12$ ve \%2'lik klorheksidin uygulamasının Clearfil S3 Bond, Clearfil SE Bond, Single Bond ve Scotchbond MP'un dentine bağlanma dayanım değerleri üzerinde anlamlı bir değişikliğe sebep olmadığını bildirmişlerdir.

\section{Çekilmiş dişin saklanma süresi:}

ISO standartlarına (11450) göre ideal bağlanma dayanım direnci, dişlerin çekimini hemen takiben elde edilir, fakat çekimi takiben dişleri test etmek 
genellikle mümkün değildir. Çekimi takiben 6 ay sonra dentin proteinlerinde dejeneratif değişikliklerin başlaması nedeniyle, çekilmiş dişler 6 aydan sonra kullanılmamalıdır. $^{2}$

Mithcem ve arkadaşları, ${ }^{64}$ dişlerin çekimden 30 dakika ya da 2 yıl sonra kullanılmasının bağlanma dayanım değerleri üzerinde olumsuz bir etkisinin olmadığını bildirmişleridir.

\section{Dişlerin çekimden sonra bulundukları bekletme solusyonu ya da ortamı:}

Diş çekiminden sonra dişler belirli bir süreye kadar dezenfeksiyon solusyonlarında kalabilirler. \%10 formalin, \%70 etanol, \%0.1-1 chloramin T, ya da \% 0.05-0.1 tymol bunlardan bazılarıdır. Ancak formalin ya da gluteraldehit kollajen ile reaksiyona girer, tymol ise polimerizasyon oranını azaltır ve bunun sonucunda adezivin performansı olumsuz etkilenir. ${ }^{17}$

Retief ve arkadaşları, ${ }^{66}$ dişlerin 3-6 ay, \% 0.05 'lik tymol solusyonunda saklandığında bağlanma dayanım değerlerinin olumsuz etkilendiğini ileri sürmüşlerdir. Lee ve arkadaşları, sığır dişlerini $37{ }^{\circ} \mathrm{C}$ 'de 60 gün distile suda, \%0.9 NaCI, \%0.5 chloramin T, \%5.25 NaOCI, \%2 gluteraldehit, \%10 formalinde bekletmişlerdir. Araştırmacılar, NaOCI solusyonunda bekletilen örneklerin düşük bağlanma dayanım değerlerini sergilediğini, \%10 formalinde bekletilen örneklerin ise bağlanma dayanım değerlerinde bir değişme olmadığını bu nedenle çekilmiş dişlerin formalinde saklanabileceğini bildirmişlerdir.

\section{Çekilmiş dişin yaşı:}

Brackett ve arkadaşları, ${ }^{67}$ total etch sistemlerin (Prime\&Bond NT) mine ve dentine olan bağlanma dayanım değerlerinin, 60 yaşının üzerindeki dişler ile daha genç dişler arasında fark oluşturmadığını ileri sürmüşlerdir. Araştırmacılar, SEM incelemelerinde yaşlı dişlerin asit uygulanan yüzeylerinde intertubuler alanlarda dekalsifikasyon derinliğinin azaldığını bildirmişlerdir.

Tagami ve arkadaşları, ${ }^{68}$ adeziv sistemlerin (Clearfil Liner Bond System, SuperBond D-Liner) dentine bağlanma dayanım değerlerini 9-21 ve 42-64 yaş aralığındaki insanlardan çekilmiş premolar dişler üzerinde incelemişler ve diş yaşı fark etmeksizin adezivlerin benzer bağlanma dayanım değerleri sergilediğini ileri sürmüşlerdir.
Özer ve arkadaşları, diş yaşının Reactmer Bond ve $A B F$ Bond'un bağlanma dayanım değerleri üzerinde etkisinin olup olmadığını incelemişlerdir. Araştırmacılar, çalışmada dişleri 20-25, 35-40 ve 50-55 yaş aralıklarına göre sınıflamışlardır. Araşırmacılar, mine bağlanma dayanım değerlerinin çalışmada kullanılan dişin yaşından etkilenmediğini bildirmişlerdir. Dentinde ise ABF Bondun bağlanma dayanım değerlerinin dişin yaşına göre değiştiğini, Reactmer Bondun bağlanma dayanım değerlerinin ise dişlerin yaşından etkilenmediğini ileri sürmüşlerdir. Araştırmacılar, her iki bağlayıcı içinde en yüksek bağlanma dayanım değerlerini 30-35 yaş aralığında ki dişlerden elde ettiklerini ve Reactmer Bond ile hazırlanan örneklerde daha çok sayıda koheziv kopma olduğunu bildirmişlerdir. Ayrıca araştırmacılar, SEM incelemelerinde yaşlı dişlerde genç dişlerden daha ince bir hibrit tabakası oluşumu gözlendiğini belirtmişlerdir. Araştırmacılar, yaşlı diş grubundaki dentinde mineral içeriğinin fazla olduğunu ve bunun bağlanma dayanım değerlerini etkilemiş olabileceğini ileri sürmüşlerdir. ${ }^{69}$

\section{Dentinin bölgesel farklılıkları:}

Perdigao ve arkadaşları, ${ }^{2}$ derin dentinde tübül sayısının artması ve bunun sonucunda dentin ıslaklığının artmasının, derin denetinde bağlanmayı karmaşık hale getirdiğini bildirmişlerdir.

Toledano ve arkadaşları, ${ }^{70}$ farklı dentin derinliklerinde bağlayıcı performanslarını (Prime\&Bond NT, Single Bond, Excite, Clearfil SE Bond, Etch\&Prime 3.0) mikrogerilim yöntemi ile incelemişlerdir. Çalışmada restorasyonların yarısını mine-dentin birleşimde (yüzeyel dentin) diğer yarısını ise mine-sement birleşimde (derin dentin) hazırlanmıştır. Araştırmacılar, Prime\& Bond NT ve Excite ile hazırlanan örneklerin bağlanma dayanım değerlerinin derin dentinde, yüzeyel dentinden anlamlı olarak yüksek olduğunu, diğer bağlayıcıların ise derin ve yüzeyel dentinde benzer bağlanma dayanım değerleri sergilediklerini ileri sürmüşlerdir. Yapılan çalışmalar derin dentinde tübül hacmnin artmasına bağlı olarak (intertubular dentinin az olmasına rağmen) tübül duvarındaki hibridize oluşumun toplam alanın artması sonucu buralarda yüksek bağlanma dayanım değerleri elde edilmiş olabileceğini bildirmiştir. ${ }^{71,72}$

Proença ve arkadaşları, ${ }^{73}$ self etch (Clearfil SE Bond, Resulcin Aqua Prime, Etch\&Prime, One Up Bond F, Prompt L Pop, Solist, Futurabond) ve total etch (Prime\&Bond NT, Single Bond) sistemlerin farklı dentin 
bölgelerinde bağlanma dayanımlarını incelemişlerdir. Restorasyonlar kronal, servikal (mine-dentin birleşimi) ve kök dentininde (mine-dentin birleşiminin $3 \mathrm{~mm}$ altı) hazırlanmıştır. Araştırmacılar, çalışmada kullanılan bütün bağlayıcıların kök dentininde düşük bağlanma değerleri sergilediğini bildirmişlerdir. Phrukkanon ve arkadaşları $^{12}$ ile Yoshiyama ve arkadaşları ${ }^{74}$, total etch sistemlerin (All Bond 2, Scotchbond Multi-Purpose, Single Bond) bağlanma dirençlerinin dentinin farklı bölgelerinden etkilenebileceğini, ancak self etch sistemlerin dentin bölgelerinden ve tübüllerin yönlenmesinden etkilenmediğini ileri sürmüşlerdir.

Munck ve arkadaşları ${ }^{75}$, dentin bağlayıcıların ( $G$ Bond, Clearfil SE Bond, Protect Bond, ScotchBond 1XT, Optibond FL) dentine bağlanma dayanımlarını, farklı dentin bölgelerinde 1 hafta, 3 ay, 6 ay ve 12 ay suda bekletme sürelerinde incelemişlerdir. Araştırmacılar, bağlayıcıların bağlanma değerlerini dişlerin merkezinden ve periferinden alınan kesitlerde ayrı ayrı değerlendirmişlerdir. Araştırmacılar, çalışmada kullanlan total etch sistemlerin bağlanma dayanım değerlerinin dentinin bölgesel farklılıklarından etkilenmediğini, ancak self-etch sistemlerin dentinin periferinden elde edilen kesitlerinde daha yüksek bağlanma dayanım değerlerleri sergilediğini ileri sürmüşlerdir. Araştırmacılar, dentinin periferinde daha yüksek bağlanma dayanım değerleri elde edilmesini buralarda intertübülar dentin miktarının artmasına bağlamışlardır. Uzun dönem suda bekletme sonucunda ise çalışmada kullanılan adezivlerin bağlanma dayanım değerlerinin dentinin bölgesel farklılıklarından etkilenmediğini bildirmişlerdir.

Yeşilyurt ve arkadaşları ${ }^{76}, 8$ farklı adeziv sistemin (Prime\&Bond NT, Single Bond, Excite, One Coat Bond, Clearfil SE Bond, Xeno III, Tyrian One Step Plus, Adper Prompt L Pop) bağlanma etkinliğini yüzeyel ve derin dentin olmak üzere iki farklı dentin bölgesinde incelemişlerdir. Araştırmacılar, çalışmada kulanılan bağlayıcı ajanların bağlanma etkinliğinin dentinin bölgesel farklılıklarından etkilenmediğini ileri sürmüşlerdir. Cavalcanti ve arkadaşları ise Clearfil SE Bond ve Single Bond ile hazırlanan clas II kavitenin tabanından elde edilen bağlanma dayanım değerinin, aksiyal duvardan elde edilen bağlanma dayanım değerinden düşük olduğu bildirmişlerdir. ${ }^{77}$

Cavalcanti ve arkadaşları, ${ }^{78}$ dentin bağlayıcıların (Single Bond Plus, Clearfil SE Bond, Adper Prompt L Pop) farklı kavite duvarlarında ki bağlanma dayanım değerlerini örneklere termo-mekanik siklus (2.000 termosiklus, 100.000 mekanik siklus) uygulayarak ve uygulamadan araştırmışlardır. Araştırmacılar, MOD kavitelerde okluzal, aksiyal ve gingival olmak üzere üç farklı bölgeden kesit alarak bu bölgelerdeki bağlanma dayanım değerlerini inclemişlerdir. Araştırmacılar, Single Bondun bağlanma dayanım değerlerinin üç farklı kavite duvarında da benzer sonuçlar sergilediğini ve Single Bond ile hazırlanan örneklerin bağlanma değerlerinin termo-mekanik siklustan etkilenmediğini, Clearfil SE Bond'un okluzal duvarda en yüksek, gingival duvarda ise en düşük bağlanma dayanım değerleri sergilediğini, L Pop'un ise üç duvarda benzer sonuçlar sergilediğini ancak termo-mekanik uygulamadan sonra gingival duvardan elde edilen bağlanma dayanım değerlerinin düştüğünü ileri sürmüşlerdir. ${ }^{78}$

\section{Yüzey hazırlığı ya da kavite preparasyonu:}

Bağlanma dayanım değerleri hibrit tabakası, reçine uzantılarının (resin tags) oluşumu ve uzunluğu ile ilişkilidir. Hibrit tabakası oluşumu, smear tabakasının kısmen kaldırılması ya da tamamen çözülmesini gerektirir. Smear tabakasında ki bu çözünmeyi takiben çözücünün buharlaşması ile intertübüler ve peritübüler dentine monomer infiltrasyonu gerçekleşir. Ayrıca, bağlayıcının ideal performansı için uygun adeziv tabaka kalınlığı oluşturulmalıdır. ${ }^{17,79,80}$

Çalışmalar, hitbrit tabaka kalınlıklarının farklı olması ile bağlanma dayanımı arasında ilişki olmadığını bildirmişlerdir. ${ }^{81-84}$ Araştırmacılar, hibrit tabakasının kalınlığından çok kalitesinin önemli olduğunu ileri sürmüşlerdir. ${ }^{82,83,85}$

Reis ve arkadaşları, ${ }^{86}$ self-etch sistemlerde (Clearfil SE Bond, Optibond Solo Plus, Scotchbond MP, Tyrian, Single Bond) smear tabaka kalınlığının bağlanma dayanım değerleri üzerindeki etkisini kısa (24 saat) ve uzun dönem ( 6 ay) suda bekleterek incelemişlerdir. Araştırmacılar, düz dentin yüzeylerini 600 grit zımpara ile zımparalayarak ince smear tabakası 60 grit zımpara ile zımparalayarak kalın smear tabakası oluşturmayı amaçlamışlardır. Araştırmacılar, çalışmada kullanılan bağlayıcıların bağlanma dayanım değerlerinin smear tabaka kalınlıklarından etkilenme- diğini, 6 ay suda bekletme sonucunda ise Scotchbond MP hariç bütün bağlayıcıların bağlanma dayanım değerlerinin düştüğünü ifade etmişlerdir.

Cho ve arkadaşları, ${ }^{24}$ tek aşamalı self ecth deneysel bağlayıcıların içeriğindeki aseton oranının farkııığının, hibrit tabaka kalınlıklarını değiştirip değiştir- 
mediğini incelemişlerdir. Araştırmacılar, bağlayıcıdaki aseton oranın artmasıyla (\%27-\%67 arasında) hibrit tabaka kalınlığı ve bağlanma dayanım değerlerinin azaldığını, \%57 ve \%67 aseton içerikli bağlayıcıların ara yüzlerinde geniş boşlukların (gap) ve çatlakların görüldüğünü bildirmişlerdir. Araştırmacılar, aseton içeriğinin artmasıyla artan ara yüz çatlaklarının, bağlanma dayanım değerlerini düşürmüş olabileceğini ileri sürmüşlerdir. Araştırmacılar, bağlayıcıdaki aseton oranının artmasıyla ara yüzde boşluk ve çatlak oluşumunun artmasını, hibrit tabakası, bağlayıcı ajan ve kompozitin farklı oranlarda polimerizasyon büzülmesi göstermesine bağlamışlardır. Araştırmacılar en yüksek bağlanma dayanım değerinin, \%37 aseton içeren bağlayıcıdan elde edildiğini bildirmişlerdir.

Tay ve Pashley ${ }^{87}, 60$ ve 600 gritlik zımparalar ile farklı kalınlıklarda smear tabakası oluşturarak, farklı pH'larda self etch sistemlerin farklı kalınlıklardaki smear tabakasına penetrasyonunu TEM ile incelemişlerdir. Araştırmacılar, hazırlanan örneklere kuvvetli asidik adeziv olan Prompt L-Pop ( $\mathrm{pH} 1)$, orta kuvvetli asidik (modarate) adeziv non-rinse conditionerPrime\&Bond NT ( $\mathrm{pH} 1,2)$, hafif asidik (mild) adeziv Clearfil Mega Bond ( $\mathrm{pH} 2$ ) olmak üzere 3 farklı self etch adeziv uygulamışlardır. Araştırmacılar, mild self adeziv uygulanan örneklerde hibrit tabaka- sında bir miktar smear artıkları kaldığını, orta kuvvetli asidik self etch adezivde smear tabakası ve smear tıkaçlarının tamamen çözüldüğünü, ancak ince bir hibrit tabakası oluştuğunu, kuvvetli asidik self etch adezivde ise smear tabakası ve smear tıkaçlarının tamamen çözüldüğünü ve oluşan hibrit tabakası kalınlığının fosforik asitle muamele edilen dentinde oluşan hibrit tabakası kalınlığına yaklaştığını ileri sürmüşlerdir. Araştırmacılar, Mega Bond ile hazırlanan örneklerde 0,4-0,5 $\mu \mathrm{m}$ ince, non-rinse conditioner-Prime\&Bond NT ile 1,2-2,2 $\mu \mathrm{m}$, L Pop ile de 2,5-5um kalınlığında hibrit tabakası oluştuğunu ileri sürmüşlerdir.

Kenshima ve arkadaşları, ${ }^{88}$ smear tabaka kalını̆̆ının ve self-etch sistemlerin pH'sının bağlanma dayanım değerlerine etkisini incelemişlerdir. Araştırmacılar, çalışmada self etch sistem olarak Clearfil SE Bond, Optibond Solo Plus, Tyrian Self Priming Echant\&One Step Plus, total etch sistem olarak Scotchbond MP, Single Bond kullanmışlardır. Farklı smear tabaka kalınlıkları 60 ve 600 gritlik zımparalar ile oluşturulmuştur. Araştırmacılar, farklı smear tabaka kalınlıklarının, reçine dentin bağlanma dayanım değerleri üzerinde etkisinin olmadığını, ancak kalın smear tabakasının ara yüzde aralık (gap) oluşumunu arttırdığını bildirmişlerdir. Araştırmacılar, self-etch primerlerin asiditesindeki farklılıkların bağlayıcıların bağlanma dayanım değerlerini etkilemediğini ve araştırmada kullanılan total etch sistemlerin en yüksek bağlanma dayanım değerleri sergilediklerini bildirmişlerdir. Araştırmacılar, total etch sistemlerin ara yüzlerinde daha küçük aralık (gap) oluşumu gözlendiğini ileri sürmüşlerdir.

Olivera ve arkadaşları, ${ }^{89}$ farklı yöntemlerle hazırladıkları yüzey işlemlerinin bağlanma üzerindeki etkisini incelemişlerdir. Araştırmacılar, elmas frez, karbit frez ve zımpara ile hazırladıkları dentin yüzeylerine Clearfil SE Bond ve Single Bond uygulamışlardır. Araştırmacılar, her iki bağlayıcı içinde en yüksek bağlanma dayanım değerinin 600 grit zımpara ile hazırlanan örneklerden, ikinci yüksek bağlanma dayanım değerlerinin karbit frez ile hazırlanan örneklerden elde edildiğini ileri sürmüşlerdir. Araştırmacılar, Single Bondun bağlanma değerlerinin ise farklı yüzey işlemlerinden anlamlı olarak etkilenmediğini ileri sürmüşlerdir.

\section{Kavite geometrisi, Konfigürasyon Faktörü (C faktörü):}

Konfigurasyon faktörü ya da C faktörü bağlayıcılı yüzeylerin bağlayıc olmayan yüzeylere oranı olarak tanımlanır. Mikrogerilim bağlanma dayanımı testi ile kavite büyüklüğünün ve tabakalama tekniğinin bağlanma değerleri üzerine etkisi incelenebilmektedir. Buna göre yüksek $\mathrm{C}$ faktörü ile bağlanma dayanımı değerleri arasında negatif ilişki vardır. Yani yüksek C faktörü, düşük bağlanma dayanım değerlerinin elde edilmesine neden olur. ${ }^{17,90}$

Araştırmacılar, genellikle Class I kavitede, kompozitin polimerizasyon büzülmesi sonucu oluşan büzülme streslerinin adezivi kavite duvarlarından uzaklaştırmak için kuvvet uyguladığını ${ }^{91,92}$ bununda ara yüzde aralık (gap) oluşumuna sebep olabildiğini ileri sürmüşlerdir. Bu durum klinikte mikrosızıntı ve post-operatif hassasiyet olarak ortaya çıkmaktadır. ${ }^{93}$

Shirai ve arkadaşları, ${ }^{94}$ polimerizasyon büzülme streslerinin bağlanma dayanım değerleri üzerindeki etkisini incelemişlerdir. Araştırmacılar, Clearfil SE Bond, L Pop, Fuji Bond LC, Reactmer, Optibond FL ve Scotchbond 1 bağlayıcıların dentine bağlanma dayanım değerlerini, düz dentin yüzeyinde ve Class I kavitede 
incelemişlerdir. Araştırmacılar, üç aşamalı sistem Optibond FL'nin polimerizasyon büzülme streslerinden etkilenmediğini, L Pop ve Fuji Bond LC ile hazırlanan örneklerin polimerizasyon büzülme streslerinden önemli ölçüde etkilendiğini ileri sürmüşlerdir.

Armstrong ve arkadaşları, ${ }^{95}$ suda bekletme ve C-faktörünün bağlanma dayanım değerleri üzerindeki etkisini incelemişlerdir. Çalışmada dentin bağlayıcı olarak Optibond FL ve Optibond doldurucusuz adeziv kullanılmıştır. Araştırmacılar, restorasyonları düz dentin yüzeyi veya kutu kavitelerde hazırlamışlar ve örnekleri 30 ve 150 gün suda bekletmişlerdir. Optibond FL'nin düz dentin yüzeyinde bağlanma dayanım değerinin 47.57 MPa, kutu kavitede ise 49.26 MPa olduğu ve aralarında anlamlı bir farklılık bulunmadığı bildirilmiştir. Ancak 150 gün suda bekletme sonunda, her iki yüzeyde de bağlanma dayanım değerlerinin (düz dentin yüzeyinde $20.90 \mathrm{MPa}$, kutu kavitede $17.49 \mathrm{MPa}$ ) anlamlı olarak azaldığı ileri sürülmüştür. Araştırmacılar, Optibond doldurucusuz bağlayıcı ajanın düz dentin yüzeyinde bağlanma dayanım değerinin 150 gün sonunda 36.93 MPa'dan 32.68 MPa'ya düştüğünü, kutu kavitede ise $32.84 \mathrm{MPa}$ dan $15.46 \mathrm{MPa}$ ya düştüğünü ve düz dentin yüzeyinde Optibond doldurucusuz bağlayıcı ajan ile hazırlanan örneklerin suda yıkıma karşı daha dayanıklı olduğunu ileri sürmüşlerdir.

Marques ve arkadaşları $^{96}, \mathrm{C}$ faktörü ve yüzey hazırlığının Clearfil SE Bondun bağlanma dayanım değerleri üzerindeki etkisini incelemişlerdir. Çalışmada restorasyonlar düz dentin yüzeyine (C-faktör=0) ve clas V kavitlere (C-faktör=3) hazırlanmıştır. Araştırmacılar, kavitelerden elde edilen bağlanma dayanım değerlerinin düz dentin yüzeyinden elde edilen değerlerden önemli ölçüde düşük olduğunu, yüksek C-faktörünün bağlanma dayanım değerleri üzerindeki olumsuz etkisinin farklı yüzey hazırlığı işlemleri ile önlenemeyeceğini bildirmişlerdir. Araştırmacılar yüzey hazırlığında karbit frez, elmas frez, 60 ya da 600 gritlik zımpara kullanılmasının bağlanma dayanım değerlerini etkilediğini, ancak bunun anlamlılık sergilemediğini ileri sürmüşlerdir.

\section{Adeziv uygulama yönteminin doğru olarak uygulanması, çözücünün uygun bir şekilde buharlaşması:}

Landuyt ve arkadaşları, ${ }^{97}$ su içermeyen tek aşamalı self etch bağlayıcı sistemlerin (Absolute, su içeren ve su içermeyen deneysel bağlayııı) teknik hassasiyet- lerini incelemişlerdir. Çalışmada üç grup oluşturulmuştur. İlk grupta düz dentin ve mine yüzeyi hava ile kurutulmuş, ikinci grupta yüzey pamuk pelet ile kurutulmuş fakat hafif nemli bırakılmış, üçüncü grupta ise yüzey ıslak (overwet) olarak bırakımışır. Araştırmacllar su içermeyen adezivlerin, pamuk pelet ile kurutulan grupta yüksek, ıslak yüzeyde ise (overwet) düşük bağlanma dayanım değerleri sergilediğini bildirmişlerdir. Araştırmacılar overwet yüzeyde düşük bağlanma dayanım değerleri olmasını, ara yüzde su damlacıklarının varlığına ve faz ayrımına bağlamışlardır.

Hiraishi ve arkadaşları, ${ }^{98}$ hava ile kurutma yöntemin bağlanma dayanım değerleri üzerindeki etkisini HEMA içermeyen self etch sistemlerde incelemişlerdir. Araştırmacılar, G Bond'un dentine bağlanma dayanım değerini hafif (gently) hava ile kurutmada 19,4 MPa, basınçlı hava ile kurutmada 30,3 MPa olarak bulunmuşlardır. Yine aynı çalışmada 3 tabaka adeziv uygulamasından sonra tek seferde hava ile kurutma sonucu $\mathrm{G}$ Bondun dentine bağlanma dayanım değeri $33,6 \mathrm{MPa}, 3$ tabaka adeziv uygulamasının her tabakasında ayrı ayrı hava sıkılması durumunda ise bağlanma dayanım değeri 37,6 MPa olarak kaydedilmiştir. Araşıırmacılar, dentine bağlanma kalitesinin basınçı hava uygulaması ile geliştirilebileceğini ancak dentin tübüllerindeki suyun ortamdan tamamen uzaklaştırılmasının imkânsız olduğunu ileri sürmüşlerdir.

Silva ve arkadaşları, ${ }^{99}$ adeziv sistemlerin (Single Bond, Scotchbond MP, Prompot L Pop) 2 tabaka olarak uygulanmasının bağlanma dayanım değerleri üzerinde ki etkisini incelemişlerdir. Araştırmacılar, Single Bondun iki tabaka uygulanması durumunda bağlanma dayanım değerlerinin düştüğünü, polimerize edilmiş Single Bondun üzerine Scotchbond MP uygulamasının bağlanma değerlerini arttırdığını, Clearfil SE Bondun iki tabaka uygulanması durumunda bağlanma dayanım değerlerinin değişmediğini, L Popun iki tabaka uygulanması sonucunda ise bağlanma dayanım değerlerinin hafif düzeyde arttığını bildirmişlerdir.

Reis ve arkadaşlar, ${ }^{100}$ adezivlerin (Single Bond, One Step) uygulama süresinin uzatılıasının bağlanma dayanım değerleri üzerindeki etkisini incelemişlerdir. Araştırmacılar adezivi 40, 90, 150 ve 300 saniye uygulayarak bağlanma dayanım değerlerindeki değişimi incelemişlerdir. Araştırmacılar, uygulama süresinin uzamasına bağı olarak her iki bağlayıının da bağlanma dayanım değerlerinin anlamlı düzeyde arttığını bildirmişlerdir. Araştırmacılar, bağlayııının uzatıımış uygu- 
lama süresinin ara yüzde bulunan artık su ve solventin ortamdan uzaklaşmasını kolaylaştırdığını, polimer dönüşüm oranını arttırarak reçinenin mekanik özelliklerini geliştirdiğini ileri sürmüşlerdir.

Elkassas ve arkadaşları, ${ }^{101}$ farklı uygulama şekillerinin bağlanma dayanım değerleri üzerindeki etkisini aseton bazlı (Prime\&Bond NT, Xeno IV, G Bond) adeziv sistemlerde incelemişlerdir. Araştırmacılar, ilk grupta adezivi üretici firma direktifleri doğrultusunda uygulamışlar, ikinci grupta iki tabaka adeziv uygulaması sonrasında ışık ile sertleştirme yapmışlar, üçüncü grupta ise her bir adeziv tabaka uygulamasından sonra ışık ile sertleştirme yaparak iki tabaka adeziv uygulamışlardır. Araştırmacılar, adezivin iki tabaka uygulanmasının Xeno IV ve G Bondun bağlanma dayanım değerlerini önemli ölçüde arttırdığını, total etch sistem olan Prime\&Bond NTde ise zit etkiye sebep olarak azalttığını ileri sürmüşlerdir. Araştırmacılar, Prime\& Bond NT'nin iki tabaka uygulanmasının adeziv tabaka kalınlığını arttırdığını ancak hibrit tabaka kalınlığını değiştirmediğini, adeziv kalınlığının artmasına rağmen hibrit tabaka kalınlığının değişmemesinin ara yüzü çekme kuvvetlerine karşı zayıf hale getirdiğini bildirmişlerdir. Araştırmacılar, Prime\&Bond NT'nin firma önerileri ile uygulanması sonucunda üç adeziv sistemden yüksek bağlanma dayanım değeri gösterdiğini ve SEM incelemesinde Prime\&Bond NT'nin uzun reçine uzantılarının sayısı ve dağılımının en yüksek düzeyde olduğunu ileri sürmüşlerdir.

Pashley ve Tay, ${ }^{102}$ self-etch adezivlerin $\mathrm{pH}^{\prime}$ sının (asit etkisinin) mine bağlanma değerleri üzerindeki etkisini incelemişlerdir. Araştırmacılar, çalışmada kuvvetli asidik adeziv olan Prompt L-Pop ( $\mathrm{pH} 1)$, orta kuvvetli asidik (modarate) adeziv non-rinse conditioner-Prime\&Bond NT ( $\mathrm{pH} 1,2)$, hafif asidik (mild) adeziv Clearfil Mega Bond ( $\mathrm{pH} 2$ ) ve kontrol grubu olarak total etch sistem \%32 $\mathrm{H}_{3} \mathrm{PO}_{4}$ ve All Bond II'yi kullanmışlardır. Aaştırmacılar, 3 self-etch sisteminde benzer bağlanma dayanım değerleri sergilediğini, total etch sistem olan All Bond II'nin diğer bağlayıcılardan yüksek bağlanma dayanım değerleri sergilediğini, self etch sistemlerin mineye balanma değerlerinin asit uygulaması ile arttırılabileceğini bildirmişlerdir. Araştırmacılar mineye bağlanma dayanım değerleri ile self etch sistemlerin $\mathrm{pH}^{\prime} \mathrm{s}$ arasında bir ilişki bulunmadığını ileri sürmüşlerdir.

\section{Örnek geometrisi}

Ghassemieh ve arkadaşları, ${ }^{18}$ örneklerin farklı geometrilerde hazırlanmasının bağlanma dayanım değerleri üzerinde etkisinin olup olmadığını incelemişlerdir. Araştırmacılar örnekleri 3 farklı geometride (çubuk, kum saati ve dumbıl şeklinde) hazırlamışlardır. Araştırmacılar kum saati şeklinde hazırlanan örneklerin bağlanma dayanım değerlerinin çubuk ve dumbıl şeklinde hazırlanan örneklerin bağlanma değerlerinden anlamlı olarak daha düşük olduğunu ileri sürmüşlerdir. Araştırmacılar, dumbıl ve çubuk şeklinde hazırlanan örneklerin bağlanma dayanım değerleri arasında anlamlı bir farklıığın olmadığını bildirmişlerdir. Araştırmacılar, ara yüzde çatlak oluşmasının ve örneklerin mikrogerilim cihazına yanlış yerleştirilmesinin bağlanma dayanım değerlerini önemli ölçüde düşürdüğünü ve bağlanma testlerinde örnek geometrisinin adezivlerin bağlanma dayanım değerleri üzerinde önemli bir etkiye sahip olduğunu belirtmişlerdir. ${ }^{18}$

Goracci ve arkadaşları, ${ }^{103}$ substrat (mine ya da dentin), örnek kalınlığı $(0.5 \times 0.5 \mathrm{~mm}, 1 \times 1 \mathrm{~mm}, 1.5 \times$ $1.5 \mathrm{~mm}, 2 \times 2 \mathrm{~mm}$ ) veya şeklinin (çubuk ya da kum saati) bağlanma dayanım değerleri üzerinde etkisini incelemişlerdir. Araştırmacılar, Clearfil SE Bond Plus ile hazırlanan örneklerin mine bağlanma değerlerinin dentinden düşük olduğunu, bağlanma dayanım değerlerinin örneklerin kalınlığının artmasıyla azaldığını ve çubuk şeklinde hazırlanan örneklerin, kum saati şeklinde hazırlanan örneklerden daha yüksek bağlanma dayanım değerleri sergilediğini bildirmişlerdir. Araştırmacılar, SEM incelemelerinde mineye bağlanma yüzeylerinde kesim sonrasında kırık ve çatlakların sıkça görüldüğünü ve eğer kum saati şeklinde örnek hazırlanacaksa bağlayıcı alanın (cross-sectional) $1 \times 1 \mathrm{~mm}^{\prime} y i$ geçmemesi gerektiğini ileri sürmüşlerdir.

Örnek çapının artmasıyla, bağlanma dayanım değerlerinin düştüğünü bildiren birçok çalışma mevcuttur. ${ }^{5,8}$ Küçük çapta hazırlanan örneklerin (crosssection alan) daha az sayıda içsel defect içermesi daha homojen stres dağılımına sebep olur. Bu durum küçük çaplı örneklerde daha yüksek bağlanma dayanım değerlerinin elde edilmesine sebep olur. ${ }^{103}$

Örneklerin kum saati şeklinde hazırlanması esnasında trimming cihazının ara yüzde ekstra stres oluşturmasının bağlanma dayanım değerlerini düşürmüş olabileceği ileri sürülmektedir. ${ }^{104}$

Phrukkanon ve arkadaşları, ${ }^{5}$ örneklerin farklı çaplarda ve geometrilerde hazırlanmasının adeziv 
sistemlerin (Optibond FL, Optibond Solo, Scotchbond MP Plus, One-step) bağlanma direnci ve ara yüzdeki stres dağılımı üzerindeki etkisini incelemişlerdir. Araştırmacılar, silindirik ve kum saati şeklinde hazırlanan örneklerin bağlayıcı alan çapını $1.1 \mathrm{~mm}^{2}, 1.5$ mm² ve $3.1 \mathrm{~mm}^{2}$ olarak hazırlamışlardır. Araştırmacılar, Optibond FL ve Optibond Solo ile hazırlanan örneklerin çapı $3.1 \mathrm{~mm}^{2}$ olanların bağlanma dayanım değerinin $1.1 \mathrm{~mm}^{2}$ olan örneklerden anlamlı olarak düşük olduğunu, örneklerin kum saati ya da silindir şeklinde hazırlanmasının bağlanma dayanım değerleri üzerinde anlamlı bir farklıı̆̆a neden olmadığını bildirmişlerdir. Araştırmacılar, bağlayıcı ara yüzeyinin küçük çapta hazırlanmasının bağlanma direncini arttırdığını ancak örneklerin farklı geometrilerde hazırlanmasının bağlanma değerleri üzerinde anlamlı bir değişikliğe sebep olmadığını ileri sürmüşlerdir.

Ermiş, ${ }^{105}$ One Coat ve Scotchbond 1XT bağlayıcı sistemleri uyguladığı örneklerin düz dentin çubuğu ya da kum saati olarak hazırlanmasının, mineye bağlanma dayanım değerleri üzerinde anlamlı bir değişikliğe neden olmadığını bildirmiştir.

\section{Uzun dönem suda bekletme:}

Bağlayıcı ara yüzeye su alımı, uzun dönemde gerçekleşen bağlayıcı yıkımının esas nedenidir. Hibrit tabakasında ki kollajen veya polimer bileşenlerin biyolojik yıkımı (biodegradasyon) bağlanama direncini etkiler. Biodegragasyon, homojen olmayan monomer dağılımı, monomerin dentine infiltrasyonun tam olarak gerçekleşememesi, ${ }^{106}$ yetersiz polimerizasyon, enzimatik kollajen yıkımı, ${ }^{107}$ faz ayrımı ${ }^{108}$ ve hidroliz ile ilişkilidir. Örneklerin suda bekleme süresinde diş olarak ya da dentin çubuğu olarak saklanması bağlanma dayanım değerlerindeki düşüşü önemli ölçüde etkiler. Yiu ve arkadaşları, reçine karışımın hidrofilik içeriğinin uzun dönem suda bekletme sonucunda gerçekleşen bağlanma dayanım değerlerindeki düşüşün sebebi oldu-ğunu, hidrofobik reçinelerin genellikle suda gerçekleşen yıkıma karşı daha dirençli olduklarını bildirmişlerdir. ${ }^{109}$

Sadek ve arkadaşları ${ }^{110}$, deneysel hidrofobik reçineyi, dentin yüzeyini 10 sn etanol ile ıslattıktan sonra uygulamışlar ve örneklerin 1 yıl suda bekletme sonunda bağlanma dayanım değerleri üzerindeki etkisini incelemişlerdir. Araştırmacılar, kontrol grubu olarak kullanılan Scotchbond MP ile hazırlanan örneklerin bağlanma dayanım değerlerinin, 1 yıl suda bekletme sonunda anlamlı olarak azaldığını (40.6 MPa'dan 27.5MPa'ya düştüğünü) ve TEM incelemelerinde ara yüzdeki bozulmanın belirgin bir şekilde izlendiğini ileri sürmüşlerdir. Araştırmacılar, etanol ile ıslatılan hidrofobik reçinenin ise bağlanma dayanım değerinin 43.7MPa'dan 39.8MPa ya düştüğünü, ancak bunun anlamlılık sergilemediğini, hidrofobik reçine ile hazırlanan örneklerin hibrit tabaka bütünlüğünün 1 yıl sonunda bile devam ettiğini bildirmişlerdir.

Burrow ve arkadaşları, ${ }^{111}$ total etch (Superbond D-liner Plus) ve self etch (Clearfil Liner Bond II) sistemlerin bağlanma dayanımlarını 7 yıl suda bekletme sonunda incelemişlerdir. Araştırmacılar, Superbond D-liner Plus'ın bağlanma dayanım değerinin 7 yıl sonunda anlamlı olarak azaldığını, Clearfil Liner II'nin bağlanma değerindeki düşüşün anlamlı olmadığını bildirmişlerdir. Araştırmacılar, Superbond ile hazırlanan örneklerde dentini demineralize etmek amacıyla kullanılan \%10 sitrik asitin (güçlü asit) ara yüzde ciddi bozulmalara sebep olduğunu bildirmiş- lerdir.

Torkabadi ve arkadaşları, ${ }^{112}$ bağlayıcı dayanıklılığını 24 saat, 3 ay, 6 ay ve 1 yıl suda bekletme sürelerinde incelemişlerdir. Araştırmacılar Clearfil S3 Bondun bağlanma dayanım değerlerinin 1 yıl suda bekletme sonunda anlamlı olarak azaldığını, G Bondun bağlanma dayanım değerlerinin ise azaldığını ancak anlamlılık sergilemediğini ileri sürmüşlerdir.

Hashimoto ve arkadaşları, ${ }^{113}$ tek aşamalı self etch bağlayıcıların (Absolute, AQ Bond Plus, G Bond, I Bond ve S3 Bond) bağlanma dayanımlarını 100, 200 ve 300 gün sürelerinde incelemişlerdir. Araştırmacılar, test edilen bütün bağlayıcıların bağlanma dayanım değerlerinin, suda bekletmenin 100. gününde düşmeye başladığını bildirmişlerdir. Araştırmacılar, ara yüzdeki bozulmaları SEM'de belirlemişler ve bunun bağlanma direncinin düşmesinin sebebi olabileceğini ileri sürmüşlerdir.

Osorio ve arkadaşları, ${ }^{114}$ on adet güncel adezivinin (AQ Sponge, Prime \&Bond NT, Single Bond, Clearfil SE Bond, Resulcin Aqua Prime, NRC Prime \&Bond NT, Etch \&Prime, Solist, Futurabond, AQ Bond, Prompt L Pop) bağlanma dayanıklılığın 24 saat 6 ay ve 1 yıl suda bekletme sürelerinde incelemişlerdir. Araştırmacilar, Single Bond, Prime\&Bond NT ve Clearfil SE bond ile hazırlanan örneklerin en yüksek bağlanma dayanım değerlerini gösterdiğini, Single Bond ve Clearfil SE Bondun bağlanma dayanım değerlerinin 1 yıl suda bekletme sonunda azalmadığını bildirmişlerdir. 
Araştırmacılar, 1 yıl sonunda Solist ile hazırlanan örneklerin bağlanma değerlerinin azaldığını, Futurabond ve Resulcin Aqua Prime uygulanan örneklerden elde edilen bütün dentin çubuklarının test öncesinde koptuğunu (pre-test failure) bildirilmişlerdir. Araştırmacılar, bağlayıcıdaki yıkım oranının adezivin içeriği ile direkt olarak ilişkili olduğunu bildirmişlerdir.

Kiyomura ve arkadaşları, ${ }^{115}$ SuperBond ile hazırladıkları örneklerin 5 yıl suda bekletme sonunda bağlanma dayanım değerlerinin 18MPa'dan (baseline) 3MPa'ya düştüğünü ileri sürmüşlerdir. Araştırmacılar, ara yüz kopmalarının başlangıçta hibrit tabakasında, suda bekletme süreleri sonunda ise hibrit tabakasının tabanında gerçekleştiğini ileri sürmüşlerdir.

\section{Termosiklus işlemi:}

Termosiklus (temal siklus, ısısal döngü) örneklerin $5^{\circ} \mathrm{C}$ ile 55 ya da $60{ }^{\circ} \mathrm{C}$ arasındaki su banyosuna, değişen siklus sayılarında muamele edilmesidir. Diş yapısı ile kompozit materyali arasındaki termal genleşme katsayısı arasındaki farklılıktan dolayı adeziv ara yüzeyinde stres oluşur. Oluşan bu streste bağlanma değerlerini etkileyebilir. ${ }^{17}$ Bazı çalışmalar, tek aşamalı self-etch sistemlerin termosiklus işleminden etkilenmediğini bildirirken, bazı çalışmalar ise termosiklus işleminden sonra tek aşamalı self etch sistemlerin bağlanma değerlerinin düştüğünü bildirmişlerdir. ${ }^{116-119}$ Adezivin kimyasal yapısına bağlı olarak, 100.000 termosiklus işleminden sonra bile ara yüzde yapısal değişiklikler meydana gelmeyebilir. ${ }^{120}$

Lodovici ve arkadaşları, ${ }^{84}$ adeziv tabaka kalınlığının, termal ve mekanik uygulamadan sonra bağlanma direncini etkileyip etkilemediğini incelemişlerdir. Clearfil SE Bond ve ScotchBond MP ile hazırlanan örnekler, bir ya da iki tabaka uygulanarak adeziv tabaka kalınlıkları SEM ile belirlenmiştir. Araştırmacılar, daha kalın ve esnek (flexible) adeziv tabaka oluşturulmasının, 1.000 termosiklus ve 500.000 mekanik siklus uygulamasının ara yüzde oluşturduğu hasarı minimize edemediğini ileri sürmüşlerdir.

\section{Test protokolü;}

Test cihazının başlık hızı (crosshead speed) sabit olmalı, cihazların kalibrasyonları yapılmalı, dişlerin kesimi kaliteli bir bıçakla ve düşük hızda, su soğutması altında yapılmalıdır. ${ }^{17,37}$ Deney süresince bağlayıcı uygulamaları tek bir uygulayıcı tarafından yapılmalı ve uygulayıcının değerler üzerinde ki etkisi en aza indirilmelidir. Alet ve gereçler detayları ile tanımlanmalı ve standardize edilmelidir. Çalışmada kullanılan her materyalin sadece marka ismi değil lot numarası da kaydedilmeli, son kullanma tarihi ve saklama koşullarına uyulmalıdır. ${ }^{17}$

Kompozit materyali, vizkoelastik özelliklere sahip olduğu için çekme testi sırasında örneklere uygulanacak hız önemlidir. Başlık hızının bağlanma dayanım değerleri üzerine etkisini değerlendiren çok az çalışma mevcuttur. ${ }^{17}$. Watanabe ve arkadaşları, ${ }^{121}$ başlık hızının shear bağlanma değerleri üzerinde anlamlı bir değişikliğe sebep olmadığını ileri sürmüşlerdir.

Leloup ve arkadaşları, ${ }^{122}$ kompozitin elastik modülüsünün, bağlayıcı alanın, örneklerin saklanma koşullarının ve test tasarımının dentine bağlanma dayanım değerleri üzerinde önemli bir etkiye sahip olduğunu ileri sürmüşleridir. Araştırmacılar, kopma modu ile bağlanma dayanım direncinin birbiri ile bağlantılı olduğunu, yüksek bağlanma dayanım değerleri olduğunda koheziv kopma oranın arttığını ileri sürmüşlerdir. Ancak, yüksek koheziv kopma oranı mükemmel adezyon gerçekleştiği anlamına gelmediğini de bildirmişlerdir.

\section{KAYNAKLAR}

1. Tagami J, Nikaido T, Nakjima M, Shimada Y. Relationship between bond strength tests and other in vitro phenomena. Dent Mater 2010; 26: 94-9.

2. Perdigao J. Dentin bonding-Variables related to the clinical situation and the substrate treatment. Dent Mater 2010; 26: 24-7.

3. Meerbeek BV, Peumans $M$, Poitevin A, Mine A, Ende AV, Neves A, Munck JD. Relationship between bond strength tests and clinical outcomes. Dent Mater 2010; 26: 100-21.

4. Barkmeier WW, Erickson RL, Kimmes NS, Lata MA, Wilwerding TM. Effect of enamel etching time on roughness and bond strength. Oper Dent 2009; 34: 217-22.

5. Phrukkanon S, Burrow MF, Tyas MJ. The influence of cross-sectional shape and surface area on the microtensile bond test. Dent Mater 1998; 14: 21221.

6. Munck JD, Landuyt KV, Peumans M,Poitevin A, Lambrechts $P$, Braem M, Meerbeek BV. A critical review of durability of adhesion to tooth tissue: Methods and results. J Dent Res 2005; 84: 118-32. 
7. Yazıcı AR, Çelik Ç, Özgünaltay G, Dayangaç B. Bond strength of different adhesive systems to dental hard tissues. Oper Dent 2007; 32: 166-72.

8. Sano H, Shono T, Sonoda H, Pashley DH. Relationship between surface area for adhesion and tensile bond strength-evaluation of a microtensile test. Dent Mater 1994; 10: 236-40.

9. Proença JP, Polido M, Osorio E, Carolina M, Erhardt G, Aguilera FS, Godoy FG, Osorio R, Toledano M. Dentin regional bond strength of self-etch and total-etch adhesive systems. Dent Mater 2007; 23: 1542-8.

10. Armstrong SR, Geraldeli S, Maia R, Raposo LHA, Soares $\mathrm{CJ}$, Yamagawa J. Adhesion to tooth structure: A critical review of micro bond strength test methods. Dent Mater 2010; 26: 50-62.

11. Ogata M, Nakajima M, Sano H, Tagami J. Effect of dentin primer application on regional bond stregth to cercival wedge-shaped cavity walls. Oper Dent 1999; 24: 81-8.

12. Phrukkanon S, Burrow MF, Tyas MJ. The effect of dentin location and tubule orientation on the bond strengths between resin and dentine. J Dent 1999; 27: 265-74.

13. Pashley DH, Carvalho RM, Sano H, Nakajima M, Yoshiyama M, Shono Y, Fernandes CA, Tay F. The microtensile bond test: a review. J Adhes Dent 1999; 1: 299-309.

14. Munck JD, Van Landuyt KL, Coutinho E, Poitevin A, Peumans M, Lambrechts P, Van Meerbeek B. Fatigue resistance of dentin/composite interfaces with an additional intermediate elastic layer. Europ J Oral Sci 2005; 113: 77-82.

15. Guzman-Armstrong S, Armstrong SR, Qian F. Relationship between nanoleakage and microtensile bond strength at the resin-dentin interface. Oper Dent 2003; 28: 60-6.

16. Scherrer SS, Cesar PF, Swain MV. Direct comparison of the bond strength results of the diffrent test methods: A critical literature review. Dent Mater 2010; 26: 78-93.

17. Salz U, Bock T. Testing adhesion of direct restoratives to dental hard tissue A Review. J Adhes Dent 2010; 12: 343-71.

18. Ghassemieh E. Evaluation of sources of uncertainties in microtensile bond strength of dental adhesive system for different specimen geometries. Dent Mater 2008; 24: 536-47.
19. Armstrong SR, Geradeli S, Maia R, Raposo LHA, Soares $\mathrm{CJ}$, Yamagawa J. Adhesion in dentistryanalyzing bond strength test methods, variables and outcomes. Adhesion to tooth structure : a critical review of 'micro' test methods. Academy of Dent MaterAnnual Meeting- Portland, Oregon, USA; October 29-31, 2009.

20. Betamar N, Cardew G, Van Noort R. Influence of specimen designs on the microtensile bond strength to dentin. J Adhes Dent 2007; 9: 59-168.

21. Poitevin A, De Munck J, Van Landuyt $K$, Couthino E, Peumans M, Lambrechts P, Van Meerbeek B. Critical analysis of the influence of different parameters on the microtensile bond strength of adhesives to dentin. J Adhesiv Dent 2008; 10: 716.

22. Eckert GJ, Platt JA. A statistical evaluation of microtensile bond strength methodology for dental adhesives. Dent Mater 2007; 23: 385-91.

23. Mine A, De Munck J, Cardoso MV, Van Landuyt KL, Poitevin A, Kuboki T. Bonding effectiveness of two contemporary self-etch adhesives to enamel and dentin. J Dent 2009; 37: 872-83.

24. Cho BH, Dickens SH. Effects of the acentone content of single solution dentin bonding agents on the adhesive layer thickness and the microtensile bond strength. Dent Mater 2004; 20 : 107-15.

25. Ceballos L, Camejo DG, Fuentesa MV, Osorio R, Toledano M, Carvalho RM, Pashley DH. Microtensile bond strength of total-etch and selfetching adhesives to caries-affected dentine. J Dent 2003; 31: 469-77.

26. Ciucchi B. Bonding characteristics of resin composite restorations on dentin Class II cavity walls, in vitro (thesis). Geneva: University of Genava, Switzerland; 1997.

27. Gamborgi GP, Loguercio $A D$, Resi A. Influence of enamel border and regional variabilty on durability of resin-dentin bonds. J Dent 2007; 35: 371-6.

28. Yoshikawa T, Sano H, Burrow MF, Tagami J, Pashley DH. Effects of dentin depth and cavity configuration on bond strength. J Dent Res 1999; 78: 898-905.

29. Armstrong S, Jessop J, Vargas M, Zou Y, Qian F, Campbell J. Effects of exogenous collagenase and cholesterol esterase on the durability of the resindentin bond. J Adhes Dent 2006; 8: 151-60. 
30. Loguercio AD, Uceda-Gomez N, Carrilho MR, Reis $A$. Inluence of specimen size and regional variation on long-term resin-dentin strength. Dent Mater 2005; 21: 224-31.

31. Ibarra G, Vargas MA, Armstrong SR, Cobb DS. Microtensile bond strength of self- etching adhesives to ground and unground enamel. J Adhesiv Dent 2002; 4: 115-24.

32. Reis A, Moura K, Pellizzaro A, Dal-Bianco K, de Andrade AM, Loguercio AD. Durability of enamel bonding using one-step self-etch systems on ground and unground enamel. Oper Dent 2009; 34: 181-91.

33. Stamatacos-Mercer C, Hottel TL. The validity of reported tensile bond strength utilizing nonstandardized specimen surface areas. An analysis of in vitro studies. Am J Dent 2005; 18: 105-8.

34. Hashimoto M, De Munck J, Ito S, Sano H, Kaga M, Oguchi $H$. In vitro effect of nanoleakage expression on resin-dentin bond strengths analyzed by microtensile bond test, SEM/EDX and TEM. Biomater 2004; 25: 5565-74.

35. Spencer P, Wieliczka DM. A Reviw of the chemical and morphologic characterization of the dentin/adhesive interface. Racent Res Dev Appl Spectrosc 1999; 2: 183-93.

36. Sadek FT, Goracci C, Cardoso PEC, Tay FR, Ferrari $M$. Microtensile bond strength of current dentin adhesives measured immediately and 24 hours after application. J Adhes Dent 2005; 7: 297-302.

37. Heintze SD. Clinical relevance of tests on bond strength, microleakage and marginal adaptation. Dent Mater 2013; 29: 59-84.

38. Pashley DH, Sano H, Ciucchi B, Yoshiyama M, Carvalho RM. Adhesion testing of dentin bonding agents: a review. Dent Mater 1995; 11; 117-25.

39. Cantoro A, Goracci C, Carvalho CA, Coniglio I, Ferrari $\mathrm{M}$. Bonding potential of self-adhesive luting agents used at different temperatures to lute composite onlays. J Dent 2009; 37: 454-61.

40. Schilke R, Lisson JA, Bauss O, Geurtsen W. Comparison of the number and diameter of dentinal tubules in human and bovine dentine by scanning electron microscopic investigation. Arch Oral Biol 2000; 45: 355-61.
41. Reis AF, Giannini M, Kavaguchi A, Soares CJ, Line $\mathrm{SR}$. Comparison of microtensile bond strength to enamel and dentin of human, bovine, and porcine teeth. J Adhes Dent 2004; 6: 117-21.

42. Zimmerli B, De Munck J, Lussi A, Lambrechts P, Van Meerbeek B. Long-term bonding to eroded dentin requires superficial bur preparation. Clin Oral Investig 2012; 16: 1451-61.

43. Karan K, Yao X, Xu C, Wang Y. Chemical profile of the dentin substrate in non-carious cercival lesions. Dent Mater 2009; 25: 1205-12.

44. Tay FR, Kwong SM, Itthagarun A, King NM, Yip HK, Moulding KM, Pashley $\mathrm{DH}$. Bonding of a selfetching primer to non-carious cervical sclerotic dentin: interfacial ultrastructure and microtensile bond strength evaluation. J Adhes Dent 2000; 2: 9-28.

45. Xie C, Han Y, Zhao XY, Wang ZY, He HM. Microtensile bond strength of one and two step self-etching adhesives on sclerotic dentin: the effects of thermocycling. Oper Dent. 2010; 35: 547-55.

46. Tsai $Y L$, Nakajima M, Wang CY, Foxton RM, Lin CP, Tagami J. Influence of etching ability of one-step self-etch adhesives on bonding to sound and noncarious cervical sclerotic dentin. Dent Mater J 2011; 30: 941-7.

47. Kwong SM, Cheung GSP, Kei LH, Itthagarun A, Smales RJ, Tay FR, Pashley DH. Micro-tensile bond strengths to sclerotic dentin using a self-etching and a total-etching technique. Dent Mater 2002; 18: 359-69.

48. Yoshiyama M, Tay FR, Doi J, Nishitani Y, Yamada $T$, Itou K. Bonding of self-etch and total-etch adhesives to carious dentin. J Dent Res 2002; 81: 556-60.

49. Nakajima M, Ogata M, Okuda M, Tagami J, Sano $\mathrm{H}$, Pashley $\mathrm{DH}$. Bonding to caries-affected dentin using self-etching primers. Am J Dent 1999; 12: 309-14.

50. Scholtanus JD, Purwanta K, Doğan N, Kleverlaan $\mathrm{CJ}$, Feilzer AJ. Microtensile bond strength of three simplified adhesives systems to caries-affected dentin. J Adhes Dent 2010; 12; 273-8.

51. Zanchi CH, D'Avila OP, Rodrigues-Junior SA, Burnett Jr LH, Demarco FF, Pinto MB. Effect of additional acid etching on bond strength and structural reliability adhesive systems applied to 
caries-affected dentin. J Adhes Dent 2010; 12; 109-15.

52. Yoshiyama M, Tay FR, Torii Y, Nishitani Y, Doi J, Itou K. Resin adhesion to carious dentin. Am J Dent 2003; 16: 47-52.

53. Ünlü N, Çetin AR, Cebe MA, Gönlüm Ö. Güncel self etch ve total etch adeziv sistemlerin çürükten etkilenmiş dentine bağlanma dayanımları. Atatürk Üniv. Diş Hek. Fak. Derg.2010;20:162-9.

54. Dishman MV, Covey DA, Baughan LW. The effect of peroxide bleaching on composite to enamel bond strength. Dent Mater 1994; 10: 33-6.

55. Sung EC, Chan SM, Mito R, Caputo AA. Effect o carbamide peroxide bleaching on the shear bond strength of composite to dental bonding agent enhanced enamel. J Prosthet Dent 1999; 82: 5959.

56. Torneck CD, Titley KC, Smith DC, Adibfar A. The influence of time of hydrogen peroxide exposure on the adhesion of composite resin to bleached bovine enamel. J Endo 1990; 16: 123-8.

57. Cadenaro M, Breschi L, Antoniolli F, Mazzoni A, Di Lenarda $R$. Influence of whitening on the degree of conversion of dental adhesives on dentin. Eur J Oral Sci 2006; 114: 257-62.

58. Leonetti ES, Rodrigues JA, Reis AF, Navarro RS, Aranha AC, Cassoni A. Microtensile bond strength of resin composite to dentin treated with Er:YAG laser of bleached teeth. Lasers Med Sci 2012; 27: 31-8.

59. Cavalli V, Liporoni PC, Rego MA, Berger SB, Giannini $M$. Influence of fluoride-containing adhesives and bleaching agents on enamel bond strength. Braz Oral Res 2012; 26: 536-42.

60. Torres RGC, Caneppele TM, Lazari DMR, Ribeiro $C F$, Borges $A B$. Effect of dental surface treatment with Nd:YAG and Er:YAG lasers on bond strength of resin composite to recently bleached enamel. Lasers Med Sci 2012; 27: 755-60.

61. Perdigao J, Denehy GE, Swift EJ. Effects of chlorhexidine on dentin surfaces and shear bond strengths. Am J Dent 1994; 7: 81-4.

62. Campos EA, Correr GM, Leonardi DP, Barato-Filho F, Gonzaga CC, Zialak JC. Chlorhexidine diminishes the loss of bond strength over time under simulated pulpal pressure and thermo-mechanical stressing. J Dent 2009; 37: 108-14.
63. Campos EA, Correr GM, Leonardi DP, Pizzatto E, Morais EC. Influence of chlorhexidine concentration on microtensile bond strength of contemporary adhesive systems. Braz Oral Res 2009; 23: 340-5.

64. Mitchem JC, Terkla LG, Gronas DG. Bonding of resin dentin adhesives under simulated physiological conditions. Dent Mater 1988; 4: 3513.

65. Retif DH, Wendt SL, Bradley EL, Denys FR. The effect of storage media and duration of storage of extracted teeth on shear bonds strength of Scotchbond 2 / Silux to dentin. Am J Dent 1989; 2: 269-73.

66. Lee JJ, Nettey-Marbell A, Cook A Jr, Pimenta LAF, Leonard R, Ritter AV. Using extracted teeth for research: the effect of storage medium and sterilization on dentin bond strengths. J Am Dent Assoc 2007; 138: 1599-603.

67. Brackett WW, Tay FR, Leooney SW, Ito S, Haisch LD, Pashley DH. The effect of subjects age on the microtensile bond strength of a resin and resinmodified glass lonomer adhesive to tooth structure. Oper Dent 2008; 33: 282-6.

68. Tagami J, Nakajima M, Shono T, Takatsu T, Hoshoda $\mathrm{H}$. Effect of aging on dentin bonding. Am J Dent 1993; 6: 145-7.

69. Özer F, Sengun A, Öztürk B, Say EC, Tagami J. Effect of tooth age on microtensile bond strength of two fluoride-releasing bonding agents. J Adhes Dent 2005; 7: 289-95.

70. Toledano M, Osorio R, Ceballos L, Fuentes MV, Carlos AOF, Tay FR, Carvalho RM. Microtensile bond strength of several adhesive systems to diffrent dentin depths. Am J Dent 2003; 16: 292-8.

71. Pashley DH, Ciucchi B, Sano H, Carvalho RM, Russel CM. Bond strength versus dentine structure: A modelling approach. Archs Oral Biol 1995; 40: 1109-18.

72. Ferrari M, Cagidiaco MC, Vichi A, Mannocci F, Mason PN, Mjor IA. Bonding of all-porcelain crowns: Structural characteristics of the substrate. Dent Mater 2001; 17: 156-64.

73. Proença JP, Polido M, Osorio E, Carolina M, Erhardt G, Aguilera FS, Godoy FG, Osorio R, Toledano M. Dentin regional bond strength of self-etch and total-etch adhesive systems. Dent Mater 2007; 23: 1542-8. 
74. Yoshiyama M, Sano H, Ebisu S, Tagami J, Ciucchi B, Carvalho RM. Regional strength of bonding agents to cercival sclerotic root dentin. J Dent Res 1996; 75: 1404-13.

75. Munck JD, Mine A, Cardoso MV, Neves ADA, Landuyt KLV, Poitevin A, Meerbeek BV. Effect of Dentin Location and long term water storage on bonding effectiveness of dentin adhesives. Dent Mater J 2011; 30: 7-13.

76. Yeşilyurt C, Bulucu B, Koyutürk AE. Adeziv sistemlerin derin ve yüzeyel dentine mikrotensile bağlanma dayanımları. İstanbul Üni Diş Hek Fak Der 2007;41:13-20.

77. Cavalcanti AN, Mitsui FH, Lima AF, Mathias $P$, Marchi GM. Evaluation of dentin hardness and bond strength at different walls of class II preparations. J Adhes Dent 2010; 12: 183-8.

78. Cavalcanti AN, Mitsui FHO, Ambrosano GMB, Mathias P, Marchi GM. Dentin bonding on different walls of a class II preparation. J Adhes Dent 2008; 10: 17-23.

79. Lohbauer U, Nikolaenko SA, Petschelt A, Frankenberger R. Resin tags do not contribute to dentin adhesion in self-etching adhesives. J Adhes Dent 2008; 10: 97-103.

80. do Amaral RC, Stanislawczuk R, Zander-Grande C, Michel MD, Reis A, Loguercio AD. Active application improves the bonding performance of self-etch adhesives to dentin. J Dent 2009; 37: 8290.

81. Meerbeek BV, Munck JD, Yoshida $Y$, Inoue $S$, Vargas M, Vijay $\mathrm{P}$, Landuyt KLV, Lambrechts $\mathrm{P}$, Vanherle G. Adhesion to enamel and dentin: Current status and future challenges. Oper Dent 2003; 28: 215-35.

82. Nakabayashi N, Saimi Y. Bonding to intact dentin. J Dent Res 1996; 75: 1706-15.

83. Perdigao J. New concepts in dental adhesion. Northwest Dent 2000; 79: 29-33.

84. Lodovici E , Reis A, Geraldeli S, Ferracane JL, Ballester RY, Filho LER. Does adhesive thickness affect resin-dentin bond strength after thermal/load cycling? Oper Dent 2009; 34: 58-64.

85. Chaves P, Giannini M, Ambrosano GM. Influence of smear layer pretreatments on bond strength to dentin. J Adhes Dent 2002; 4: 191-6.
86. Reis A, Grandi V, Carlotto L, Bortoli G,Patzlaff $R$,Lourdes $M$, Loguercio AD. Effect of smear layer thicness and acidity of self-etching solitions on erly and long term bond strength to dentin. J Dent 2005; 33: 549-59.

87. Tay FR, Pashley DH. Aggressiveness of contemporary self-etching systems. I: Depth of penetration beyond dentin smear layers. Dent Mater 2001; 17: 296-308.

88. Kenshima S, Reis A, Gomez NU, Tancredo LLF, Filho LER, Nagueira FN, Loguercio AD. Effect of smear layer thickness and $\mathrm{pH}$ of self-etching adhesive systems on the bond strength and gap formation to dentin. J Adhes Dent 2005; 7: 11726.

89. Oliveira SSA, Pugach MK, Hilton JF, Watanabe LG, Marshall SJ, Marshall GW. The influence of the dentin smear layer on adhesion: a self-etching primer vs. a total-etch system. Dent Mater 2003; 19: 758-67.

90. He Z, Shimada Y, Tagami J. The effects of cavity size and incremental technique on micro-tensile bond strength of resin composite in Class I cavities. Dent Mater 2007; 23: 533-8.

91. Feilzer AJ, De Gee AJ, Davidson CL. Setting stress in composite resin in relation to configuration of the restauration. J Dent Res 1987; 66: 1636-9.

92. Versluis A, Douglas WH, Cross M, Sakaguchi RL. Does an incremental filling technique reduce polymerization shrinkage stresses? J Dent Res 1996; 75: 871-8.

93. Roulet JF. Marginal integrity: clinical significance. J Dent 1994; 22: 9-22.

94. Shirai K, Munck JD, Yoshida $Y$, Inoue $S$, Lambrechts P, Suziki K, Shintani H, Meerbeek BV. Effect of cavity configuration and aging on the bonding effectiveness of six adhesives to dentin. Dent Mater 2005; 21: 110-24.

95. Armstrong SR, Keller JC, Boyer DB. The influence of water storage and $\mathrm{C}$-factor on the dentin-resin composite microtensile bond strength and debond pathway utilizing a filled and unfilled adhesive resin. Dent Mater 2001; 17: 268-76.

96. Marques MSM, Kenshima S, Muench A, Ballester RY, Filho LER. Effect of the c-factor and dentin preparation method in the bond strength of a mild self-etch adhesive. Oper Dent 2009; 34: 452-9. 
97. Landuyt KLV, Mine A, Munck JD, Countinho E, Peumans M, Jaecques S, Lambrechts $P$, Meerbeek BV. Technique sensitivity of water-free one-step adhesives. Dent Mater 2008; 24: 1258-67.

98. Hiraishi N, Breschi L, Prati C, Ferrari M, Tagami J, King NM. Technique sensitivity associated with airdrying of HEMA-free, single-bottle,one-step selfetch adhesives. Dent Mater 2007; 23: 498-505.

99. Silva ALF, Lima DANL, Souza GMD, Santos CTD, Paulillo LAMS. Influence of additional adhesive aplication on the microtensile bond strength of adhesive systems. Oper Dent 2006; 31: 562-8.

100. Reis A, Cardoso P, Vieira L, Baratieri L, Grande R, Loguercio AD. Effect of prolonged applicatin times on the durability of resin-dentin bonds. Dent Mater 2008; 24: 639-44.

101. Elkassas D, Taher HA, Elsahn N, Hafez R, ElBadrawy W. Effect of the number of applicaitons of acetone-based adhesives on microtensile bond strength and the hybrid layer. Oper Dent 2009; 34: 688-96.

102. Pashley DH, Tay FR. Aggressiveness of contemporary self-etching adhesives Part II: etching effects on unground enamel. Dent Mater 2001 ; 17: 430-44.

103. Goracci C, Sadek FT, Monticelli F, Cardoso PEC, Ferrari M. Influence of substrate, shape, and thickness on microtensile specimens structural integrity and their measured bond strengths. Dent Mater 2004; 20: 643-54.

104. Bouillaguet S, Ciucchi B, Jacoby T, Wataha JC, Pashley D. Bonding characteristics to dentin walls of Class II cavities, in vitro. Dent Mater 2001; 17:316-21.

105. Ermiş RB. Kullanılan test araçlarının mikrogerilme bağlanma dayanımı ölçümlerindeki etkisinin değerlendirilmesi. Hacettepe Diş Hek Fak Derg 2008; 32:94-102.

106. Yoshida E, Uno S, Noasaka Y, Kaga M, Hirano S. Relationship between water status in dentin and interfacial morphology in all-in-one adhesives. Dent Mater 2007; 23: 556-60.

107. Pashley DH, Tay FR, Yiu C, Hashimoto M, Breschi L, Carvalho RM, Ito S. Collagen degradation by host-derived enzymes during aging. J Dent Res 2004; 83: 216-21.
108. Spencer P, Wang Y. Adhesive phase separation at the dentin interface under wet bonding conditions. J Biomed Mater Res 2002; 62: 44756.

109. Yiu CKY, King NM, Pashley DH, Suc BI,. Carvalho RM, Carrilho MRO, Tay FR. Effect of resin hydrophilicity and water storage on resin strength. Biomater 2004; 25: 5789-96.

110. Sadek FT, Castellan CS, Braga RR, Mai S, Leo T, Pashley DH, Tay FR. One year stability of resindentin bonds created with a hydrophobic ethanol-wet bonding technique. Dent Mater 2010; 26: 380-6.

111. Burrow MF, Harada N, Kitasako Y, Nikaido T, Tagami J. Seven-year dentin bond strengths of a total- and self-etch system. Eur J Oral Sci 2005; 113: 265-70.

112. Torkabadi S, Nakajima $M$, Ikeda $M$, Foxton RM, Tagami J. Bonding durabilty of HEMA-free and HEMA containing one-step adhesives to dentine surrounded by bonded enamel. J Dent 2008; 36: 80-6.

113. Hashimoto M, Fujita S, Kaga M, Yawaka Y. In vitro durability of one-bottle resin adhesives bonded to dentin. Dent Mater J 2007; 26: 67786.

114. Osorio R, Proenca JP, Erhardt MCG, Osorio E, Aguilera F, Tay FR, Toledano M. Resistance of ten contemporary adhesives to resin-dentine bond degradation. J Dent 2008; 36: 163-9.

115. Kiyomura $M$. Bonding strength to bovine dentin with 4 META/ MMA-TBB resin: Long term stability and influence of water. J Jpn Dent Mater 1987; 6: 860-72.

116. Abdalla Al, El Zohairy AA, Aboushelib MM, Felizer AJ. Inluence of thermal and mechanical load cycling on the microtensile bond strength of selfetching adhesives. Am J Dent 2007; 20: 250-4.

117. Asaka $Y$, Yamaguchi $K$, Inage $H$, Takamizawa $T$, Kurokawa H, Rikuta A, Kuroda T, Miyazaki M. Effect of thermal cycling on bond strengths of single-step self-etch adhesives to bovine dentin. J Oral Sci 2006; 48: 63-9.

118. Asaka Y, Amano S, Rikuta A, Kurokawa $H$, Miyazaki M, Platt JA and Moore BK. Influence of thermal cycling on dentin bond strengths of single-step self-etch adhesive systems. Oper Dent 2007; 32: 73-8. 
119. Akın GE, Hergüner-Siso Ş, Akın H. Termal siklus ve suda bekletmenin kendinden asitli adezivlerin dentine mikrogerilim bağlanma dayanımları üzerine etkileri. J Dent Fac Atatürk Üni 2012; 22: 125-31.

120. Inoue $S$, Koshiro $K$, Yoshida $Y$, De Munck J, Nagakane K, Suziki K, Sano H, Van Meerbeek B. Hydrolytic stability of self-etch adhesives bonded to dentin. J Dent Res 2005; 84: 1160-4.

121. Watanabe LG, Marshall GW, Marshall SJ. Variables influence on shear bond strength testing to dentin. Advanced Adhesive Dentistry3rd International Kuraray Symposium,1999; 7590.

122. Leloup G, D'Hoore W, Bouter D, Degrange $M$, Vreven J. Meta-analytical review of factors involved in dentin adherence. J Dent Res 2001; 80: 1605-14.

\section{Yazışma Adresi}

Dr. Neslihan TEKÇE

Ataşehir Ağız ve Diş Sağlığı Merkezi, Selviburnu Subay Lojmanları

Şahin Sok Şahin Ap D:3

BEYKOZ/İSTANBUL

Tel: 5428190095

e-mail: neslihan_arslann@hotmail.com 